\title{
The petrogenesis of tholeitic diabases in eastern Parnaíba Basin: evidence for geochemical heterogeneities in the subcontinental lithospheric mantle in NE Brazil
}

\author{
Petrogênese de diabásios toleíticos na porção oriental da Bacia do \\ Parnaíba: evidências para heterogeneidade no manto litosférico \\ subcontinental no NE do Brasil
}

Adriano Guilherme da Silva ${ }^{1}$, Cícera Neysi de Almeida ${ }^{1}$, Sérgio de Castro Valente ${ }^{2 *}$, Leonardo Fonseca Borghi de Almeida ${ }^{1}$

\begin{abstract}
The sedimentary rocks within the Paleozoic Parnaiba basin in NE Brazil were intruded by voluminous tholeiitic diabase sills and covered by coeval basaltic flows. This paper presents lithogeochemical data of borehole samples obtained from wells located in the eastern portion of the Parnaiba basin. The diabases are subalkaline tholeiitc rocks comprising three high- $\mathrm{TiO}_{2}$ and three low- $\mathrm{TiO}$, suites that are unrelated by differentiation processes. Fractional crystallization of olivine and augite was the predominantly evolutionary processes within individual high-and low-TiO, suites as depicted by trace element geochemical modelling, exception being made for one low-TiO suite that evolved by AFC. Parental compositions for both low- and high-TiO 2 suites are related with variably enriched, spinel harzburgitic sources likely to represent the heterogeneous subcontinental lithospheric mantle underneath the sedimentary basin. The geochemical provinciality of the Parnaiba tholeiitic magmatism seems unrelated with the Transbrasiliano Lineament but may be due to lithospheric mantle amalgamation and remobilization occurred during previous tectonic events.
\end{abstract}

KEYWORDS: Transbrasiliano; Parnaiba basin; Diabases.
RESUMO: As rochas sedimentares paleozóicas da Bacia do Parnaíba, no Nordeste do Brasil, foram intrudidas por soleiras volumosas de diabásio tolético e cobertas por derrames basálticos. Este artigo apresenta dados geoquímicos obtidos a partir de amostras de poços da porção leste da bacia sedimentar. Os diabásios são subalcalinos, toléticos e agrupam-se em três suites de alto- $\mathrm{TiO}_{2}$ e três de baixo- $\mathrm{TiO}_{2}$ não relacionadas por processos de diferenciação. Os processos petrogenéticos foram investigados com base em modelagem geoquímica e revelaram que as suites toleíticas evoluíram por cristalização fracionada de augita e olivina à exceção de uma, de baixo- $\mathrm{TiO}_{2}$, evoluída por $\mathrm{AFC}$ em câmaras magmáticas pequenas na crosta superior. As composiçóes parentais de ambas as suites, de baixo- $\mathrm{TiO}_{2}$ e alto- $\mathrm{TiO}_{2}$, estáo relacionadas com fontes mantélicas harzburgíticas variavelmente enriquecidas dentro da zona de estabilidade espinélio representadas pelo manto litosférico subcontinental. Esta fonte mantélica é lateralmente e/ou verticalmente quimicamente heterogênea e a provincialidade geoquímica em escala local parece não ter sido controlada pelo Lineamento Transbrasiliano, mas sim por remobilização do manto litosférico subcontinental possivelmente amalgamado durante processos orogênicos colisionais ocorridos previamente.

PALAVRAS-CHAVE: Transbrasiliano; Bacia do Parnaíba; Diabásios.

\footnotetext{
1Universidade Federal do Rio de Janeiro - UFRJ, Rio de Janeiro (RJ),Brazil.E-mail:adr.geoscientist@gmail.com; neysi@geologia.ufrj.br; lborghi@geologia.ufrj.br ²Universidade Federal Rural do Rio de Janeiro - UFRRJ, Seropédica (RJ), Brazil. E-mail: sergio@ufrrj.br

*Corresponding author.

Manuscript ID: 20160041. Received in: 03/16/2016. Approved in: 02/08/2017.
} 


\section{INTRODUCTION}

Tholeiitic basalt flows and diabase intrusions (dykes and sills) occur associated with the sedimentary rocks of the Paleozoic Parnaíba basin in northeast Brazil (Aguiar 1969). These magmatic rocks comprise the Mosquito Formation (199 $\pm 2,4 \mathrm{Ma} ;{ }^{40} \mathrm{Ar} /{ }^{39} \mathrm{Ar}$ in plagioclase; Merle et al. 2011) and the Sardinha Formation (c.a. 129-124 Ma; K-Ar and ${ }^{40} \mathrm{Ar} /{ }^{39} \mathrm{Ar}$, whole-rock; Bellieni et al. 1990, Fodor et al. 1990). The former has been associated with the Central Atlantic Magmatic Province (CAMP; Marzoli et al. 1999) and the break-up of Pangea, prior to the opening of the Central Atlantic Ocean in the Florida-Guyana-Liberia area (e.g., Bertrand 1991) whereas the latter has been related with the Paraná-Etendeka Continental Flood Basalt Province and the fragmentation of Gondwana, previously to the opening of the South Atlantic ocean (Bellieni et al. 1990).

The tholeiitic dykes and sills are interbedded with the Paleozoic sedimentary rocks of the Pimenteiras and Cabeças formations (Devonian), the Poti Formation (Mississipian), and the Piauí Formation (Pensylvanian) of the Parnaíba basin (Vaz et al. 2007). The sedimentary rocks within these formations are related with the petroleum systems identified in this Paleozoic basin (Abelha 2013). The magmatic rocks of the Sardinha and Mosquito formations played their role in the generation and migration as well as sealing and trapping of hydrocarbons (e.g. Rodrigues 1995).

Previous works on the tholeiitic magmatism within the Parnaíba basin were done on the basis of petrographic, geochemical and geochronological data obtained from surface samples (Bellieni et al. 1990, Fodor et al. 1990, Baksi \& Archibald 1997, Marzoli et al. 1999, Ernesto et al. 2004, Merle et al. 2011). In this paper we present new petrographic and lithogeochemical data obtained from borehole samples of the Parnaíba tholeiitic rocks and put constraints on the geochemical heterogeneity of the subcontinental lithospheric mantle beneath the Parnaíba sedimentary basin in NE Brazil.

\section{GEOLOGICAL FRAMEWORK OF THE PARNAÍBA BASIN}

The Parnaíba basin is located in northeastern Brazil (Fig. 1). It extends over $6.7 \times 10^{5} \mathrm{~km}^{2}$ with approximately 3,500 $\mathrm{m}$ of maximum thickness of sediments (Vaz et al. 2007). The sedimentation of immature siliciclasts started in the Late Cambrian and Early Ordovician (Jaibaras Group) and took place onto grabens originated from the separation of Laurentia and Baltica (Bond et al. 1984, Oliveira \& Mohriak 2003). The stratigraphic record of the Parnaíba basin can be divided into three main sedimentary cycles during the Silurian, the Devonian and the Permian-Carboniferous separated by well-marked unconformities all over the basin (Goes et al. 1990). These three sedimentary cyles are related with five sedimentary supersequences from the begining of the Paleozoic to the end of the Cretaceous, including two magmatic episodes represented by the tholeiitic basalts and diabases of the Mosquito Formation (Triassic) and the Sardinha Formation (Cretaceous) (Aguiar 1969).

The main regional structures within the Parnaíba basin are the NE-trending, Transbrasiliano Lineament and the NW-trending, Picos-Santa Inês Lineament (Fig. 1), which controlled the main NE and NW depositional axis from the Early Silurian up to the Early Carboniferous. Later on, the basin acquired the typical oval shape of a syneclise leading to the migration of the depocenter to the central parts of the basin (Vaz et al. 2007). Recent small magnitude, shallow depths earthquakes $(<60 \mathrm{~km})$ within the northeast part of the basin (Lima Neto 2013) might be related to the reactivation of ENE-WSW-trending shear zones (Médio Coreaú Domain) extending far below the basin eastwards the Borborema Province.

Gravimetric and seismic data show that the thickness of the continental crust in the area of the Parnaíba basin does not exceed $40 \mathrm{~km}$ (Assumpção et al. 2013, Castro et al. 2014) with Moho at shallow to intermediate depths in the northeast and central portions of the basin. The boreholes of the present study are located in this area (Fig. 1).

\section{PREVIOUS WORK ON THE PARNAÍBA BASALTS}

The tholeiitic basalts of the Sardinha Formation prevail eastwards whereas those of the Mosquito Formation prevail westwards the Parnaíba basin (e.g., Fodor et al. 1990; Ernesto et al. 2004). Some authors proposed that the high- $-\mathrm{TiO}_{2}$ Sardinha and low- $-\mathrm{TiO}_{2}$ Mosquito basalts could be distinguished on the basis of the higher $\mathrm{Ti}, \mathrm{Ba}$, $\mathrm{La}, \mathrm{Ce}, \mathrm{Y}, \mathrm{Zr}$, and Sr contents of the former (Bellieni et al. 1990). Nevertheless, low- $\mathrm{TiO}_{2}$ basalts were later recognised in the Sardinha Formation (Baksi \& Archibald 1997) and distinction from their counterparts within the Mosquito Formation are difficult to be made on the basis of petrological data.

Geochronological K-Ar data obtained for the Mosquito basalts (Fodor et al. 1990) peaked at ca. $160 \mathrm{Ma}$ and $c a$. $200 \mathrm{Ma}$ whilst for the Sardinha basalts ages spreaded over ca. $130 \mathrm{Ma}$ and ca. $115 \mathrm{Ma}$. Later, ${ }^{40} \mathrm{Ar} /{ }^{39} \mathrm{Ar}$ data pointed to $c a .200-190 \mathrm{Ma}$ for the low-TiO 2 Mosquito basalts, and $c a .129-124 \mathrm{Ma}$ for the high- $\mathrm{TiO}_{2}$ Sardinha basalts as well as ca. $123 \mathrm{Ma}$ for their low- $\mathrm{TiO}_{2}$ counterparts (Baksi 
\& Archibald 1997). More recent ${ }^{40} \mathrm{Ar} /{ }^{39} \mathrm{Ar}$ ages on plagioclase separates gave $196 \pm$ 1,0 Ma, 198,0 \pm 1,2 Ma and $199,2 \pm 1,0 \mathrm{Ma}$ for the high-TiO 2 basalts of the Mosquito Formation, i.e., coeval to the low- $\mathrm{TiO}_{2}$ ones (Merle et al. 2011). In general, the geochronological data corroborates the association of the high- and low- $\mathrm{TiO}_{2}$ Mosquito basalts with the tectonic events related with the opening of the Atlantic ocean at equatorial latitudes as well as the highand low- $-\mathrm{TiO}_{2}$ Sardinha basalts with the fragmentation of Gondwana prior to the opening of the South Atlantic ocean.
It is now generally accepted by many authors that highand low- $\mathrm{TiO}_{2}$ basalts, dykes and sills occur both in the Mosquito and Sardinha formations in the Parnaíba basin (Bellieni et al. 1990, Fodor et al. 1990, Baksi \& Archibald 1997, Marzoli et al. 1999, Ernesto et al. 2004, Merle et al. 2011). Previously to the publication of geochronological data, petrogenetic studies proposed that the high- $\mathrm{TiO}_{2}$ Sardinha basalts and the low- $\mathrm{TiO}_{2}$ Mosquito basalts could not be related to each other by fractional crystallization without or with concomitant assimilation (ie. AFC, DePaolo 1981)

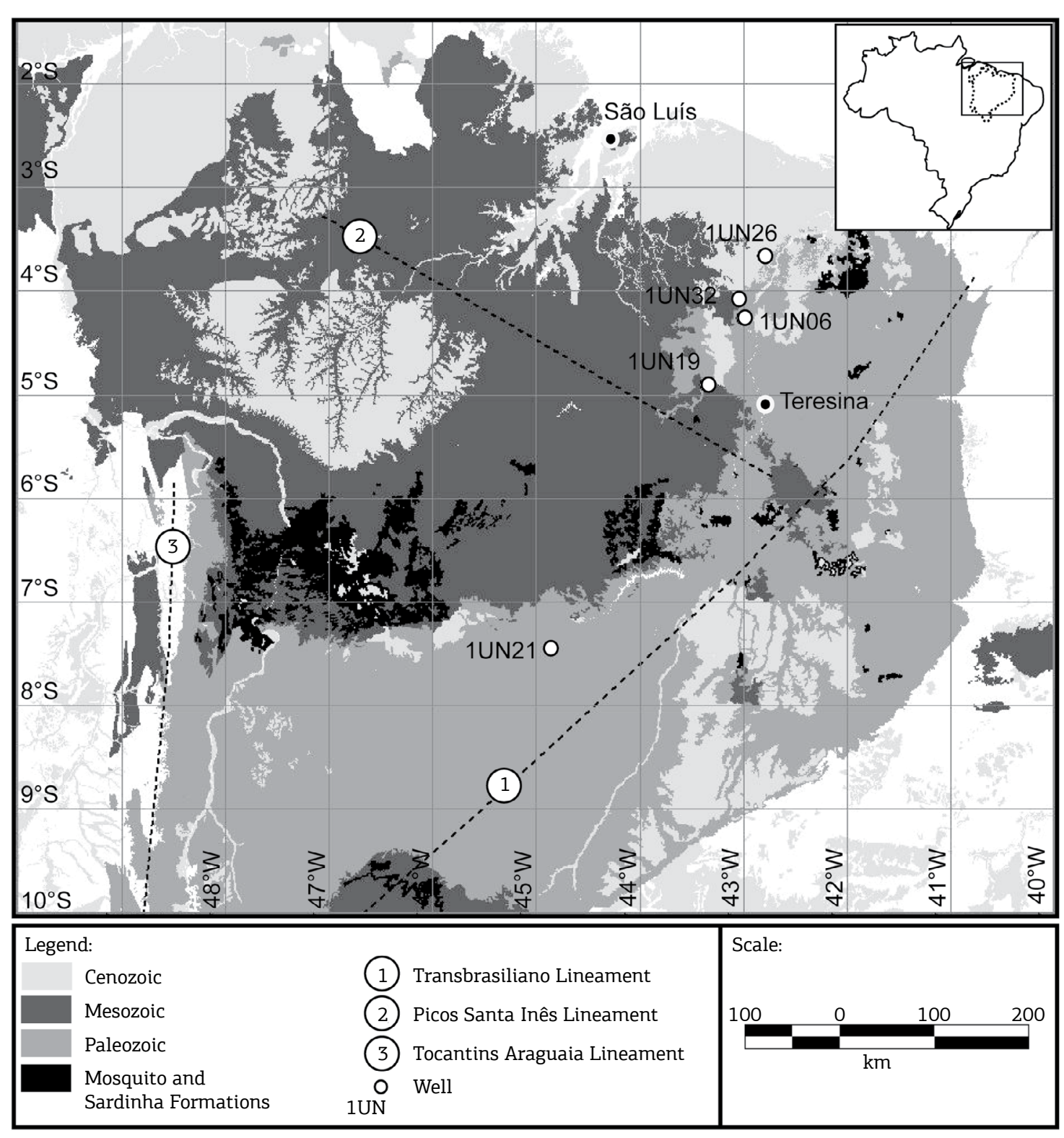

Figure 1. Phanerozoic sedimentary cover and major lineaments of the Parnaíba basin. The boreholes sampled during this study are indicated (eg. 1UN21). As an approximation, the $45^{\circ} \mathrm{W}$ longitude circle separates the Mosquito Formation, to the west, from the Sardinha Formation, eastwards the Parnaíba basin. 
althought the low- $-\mathrm{TiO}_{2}$ Mosquito basalts themselves seemed to be related by AFC at low pressures (Bellieni et al. 1990). These authors proposed that the compositions of the high$-\mathrm{TiO}_{2}$ Sardinha and the low- $\mathrm{TiO}_{2}$ Mosquito parental magmas could be explained by either 8 and $25 \%$ of partial melting of a garnet peridotite source or $10 \%$ of partial melting from a garnet and spinel source, respectively. Dynamic models also pointed to generation of the Sardinha and Mosquito basalts by 5 and $20 \%$ partial melting of a spinel source with $2 \%$ of magma retention in the residue.

More recent petrological work recognized two non-cogenetic high- $\mathrm{TiO}_{2}$ and three low- $\mathrm{TiO}_{2}$ suites in the Mosquito basalts in the west part of the Parnaíba basin (Merle et al. 2011). The origin of the high- $\mathrm{TiO}_{2}$ suites was attributed to partial melting of asthenospheric sources contaminated by interaction with the subcontinental lithospheric mantle. More evolved compositions were related to further AFC processes during ascent to crustal levels. On the other hand, the low- $\mathrm{TiO}_{2}$ basalts were related to partial melting of the most enriched portions of the subcontinental lithospheric mantle whose metassomatization was associated with previous subduction processes. Nevertheless, the participation of asthenospheric sources in the generation of the low- $\mathrm{TiO}_{2}$ Mosquito basalts was not completely refused by those authors. The authors proposed that the high- and the low- $\mathrm{TiO}_{2}$ Mosquito basalts are related to local anomalously hot mantle conditions due to combined effects of edge-driven convection and large-scale mantle warming beneath the Pangea supercontinent, although a mantle-plume component with asthenospheric-like isotopic characteristics was not ruled out neither as a main source nor as a heat supplier.

\section{BOREHOLE SAMPLING AND ANALYTICAL METHODS}

The boreholes are located along an approximately NNE trend subparallel to the Transbrasiliano Lineament (Fig. 1). The farmost boreholes (1UN21 and 1UN26) are located about $400 \mathrm{~km}$ apart but boreholes can be displaced from each other by just about $20 \mathrm{~km}$ (1UN06 and 1UN32).

Thirty-four samples were collected from the boreholes within the study area. They were prepared for petrography and a subset with twenty-two samples was used for lithogeochemical analysis. Criteria for sample selection for lithogeochemical analysis were based on the absence of amygdales and veins, alteration products as well as phenocrysts as much as possible. Samples were washed under destiled water, dried, crushed under a cutrock device and furtherly reduced to powder $(-10 \mathrm{~g})$ under 200\# in a WC mill. Samples powders were sent to ACTLABS in Canada for analyses of major and trace elements, including the Rare Earth Elements (REE). A $1 \mathrm{~g}$ aliquota of each sample powder was fused and then digested with aqua regia and diluted to $250 \mathrm{~mL}$ volumetrically. Appropriate international reference materials were digested at the same time. The samples and standards were analyzed on a Thermo Jarrell Ash ENVIRO II simultaneous and sequential ICP-AES for $\mathrm{SiO}_{2}, \mathrm{TiO}_{2}, \mathrm{Al}_{2} \mathrm{O}_{3}, \mathrm{Fe}_{2} \mathrm{O}_{3}{ }^{\mathrm{t}}, \mathrm{MnO}, \mathrm{MgO}, \mathrm{CaO}$, $\mathrm{Na}_{2} \mathrm{O}, \mathrm{K}_{2} \mathrm{O}$, and $\mathrm{P}_{2} \mathrm{O}_{5}$. Total iron was analysed as $\mathrm{Fe}_{2} \mathrm{O}_{3}{ }^{\mathrm{t}}$. Loss on ignition (LOI) was performed by measuring weight differences before and after heating another $1 \mathrm{~g}$ aliquota of the same sample powder in furnace at $1100^{\circ} \mathrm{C}$ for 30 minutes. Detection limits were $0.01 \mathrm{wt} . \%$ for the analysed oxides and LOI, but 0.001 wt. $\%$ for $\mathrm{MnO}$ and $\mathrm{TiO}_{2}$. Afterwards, a $0.25 \mathrm{~g}$ aliquota of sample powder was digested with four acids beginning with hydrofluoric, followed by a mixture of nitric and perchloric acids, heated using precise programmer controlled heating in several ramping and holding cycles which takes the samples to dryness. After dryness was attained, samples were brought back into solution using hydrochloric acid. Selected trace elements (Ni, Cr, Sc, Co, V, Ba, Rb, Sr, $\mathrm{Nb}, \mathrm{Y}, \mathrm{Zr}, \mathrm{Hf}, \mathrm{U}, \mathrm{Th}, \mathrm{Pb}$, and the whole set of REE) were measured in samples and standards by Perkin Elmer Sciex ELAN 9000 ICP/MS. Three blanks and five controls (three before sample group and two after) were analyzed per group of samples. Duplicates were fused and analyzed every $15 \mathrm{sam}$ ples. Instrument was recalibrated every 40 samples. Detection limits for the selected trace elements were as follows: $\mathrm{Ni}$ and $\mathrm{Cr}(20 \mathrm{ppm}), \mathrm{Sc}$ and Co (1 ppm), V (5 ppm), Ba (3 ppm), Rb (1 ppm), $\mathrm{Sr}(2 \mathrm{ppm}), \mathrm{Nb}(0.2 \mathrm{ppm}), \mathrm{Y}(0.5 \mathrm{ppm}), \mathrm{Zr}$ (1 ppm), Hf (0.1 ppm), U (0.01 ppm), Th (0.05 ppm), Pb (5 ppm), and below chondritic values for REE. Accuracy was measured on the basis of international standards W-2a (oxides and some trace elements), BIR-1a (Ni, La, Eu, and Gd), and ZW-C $(\mathrm{Nb})$ whereas precision was measured by duplicating sample $1 \mathrm{UN} 06 / 178,90$, according to the method proposed by Jenner (1996) and Jenner et al. (1990). As such, precision values on the basis of percentages of relative standard deviations (\%RSD) varied from 0.00 to 2.56 (average of 0.6 ) for oxides, 0.00 to 0.75 (average of 0.3 ) for $\mathrm{Ni}, \mathrm{Cr}, \mathrm{Sc}$, and $\mathrm{Co}$, 0.00 to 2.22 (average of 1.1) for the other selected trace elements, and 0.00 to 4.76 (average of 1.5) for REE. Accuracy values on the basis of percentage of relative differences (\%RD) varied from 0.0 to \pm 4.2 (average of \pm 1.9 ) for oxides, 0.00 to \pm 8.7 (average of \pm 4.9 ) for $\mathrm{Ni}, \mathrm{Cr}, \mathrm{Sc}$, and $\mathrm{Co}, \pm 1$ to \pm 9.5 (average of \pm 5.9 ) for the other selected trace elements, and 0.00 to \pm 6.5 (average of 3.4) for REE. According to those authors criteria, precision and accuracy values can be considered excelent (0 to 3\%RSD) and very good (3 to 7\%RSD) for most of analysed oxides and trace elements. Accuracy values for $\mathrm{V}, \mathrm{Cr}, \mathrm{Rb}, \mathrm{Zr}, \mathrm{Hf}$, and $\mathrm{Th}$ can be considered good $( \pm 7-10 \% \mathrm{DR})$ based on the same criteria. 


\section{RESULTS}

\section{Petrography}

The studied samples are basalts and diabases, which were arbitrarily distinguished by their amount of volcanic glass (respectively, > 50 vol.\% and < 50 vol.\%) since distinction could not be made on field relationships criteria. Textures and structures were described following MacKenzie et al. (1982). The rocks vary from aphanitic to phaneritic, the latter being fine $(<1 \mathrm{~mm})$, medium- $(1-3 \mathrm{~mm})$ or coarse-grained $(>3 \mathrm{~mm})$ types. Both hypo- to holohyalline rocks were found, the latter being predominantly equigranular and, more rarely, porphyritic. Zoned, partially corroded laths of plagioclase with sieve textures, as well as euhedral to subhedral augite and olivine pseudomorphs altered to bowlingite and iddingsite occur in the porphyritic rocks. The textures of the plagioclase crystals (Fig. 2) indicate that they were not in equilibrium with the host magma and may represent either antecrysts or xenocrysts. Augite phenocrysts largely predominate over olivine ones. Intersertal and intergranular textures are common, with subordinate ophitic and subophitic ones. Essential minerals within the groundmass include plagioclase and augite with apatite and Fe-Ti oxides as accessory phases. Myrmekite and microgranophyric textures are common, pointing to the relatively evolved compositions of the original basaltic magmas (Fig. 3). Alteration products include bowlingite and iddingsite over olivine, uralite over augite and saussurite over plagioclase. Veins and amygdales

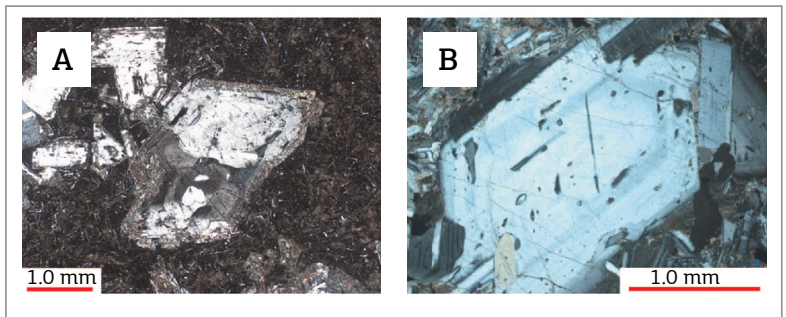

Figure 2. Corroded (A) and zoned (B) plagioclase xenocrysts in diabases from the Parnaíba basin. Crossed polarized light. Samples: 1 UN06 and 1UN32.

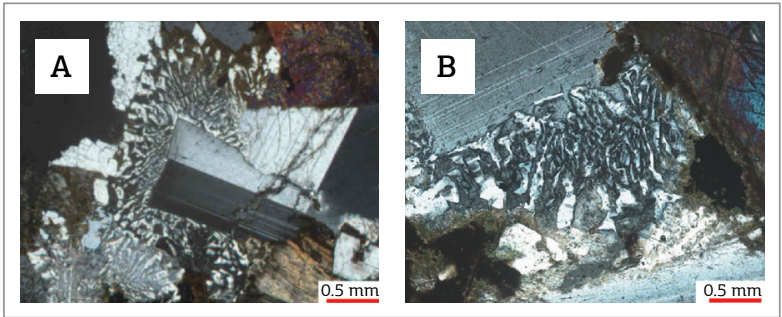

Figure 3. Myrmekite in diabase (A) and basalt (B) from the Parnaíba basin. Crossed polarized light. Samples: 1UN26. were found in some samples, particularly in those from the central portion of borehole $1 \mathrm{UN} 32$.

\section{Lithogeochemistry}

The lithogeochemical data of the studied samples are shown in Table 1. The Parnaíba basalts and diabases sampled from the five boreholes comprise a subalkaline, tholeiitic series (Fig. 4). The rocks are classified as basalts and basaltic andesites in the TAS diagram. CIPW norm calculations (Tab. 2) showed that all samples are hypersthene normative with no nepheline, which corroborates their tholeiitic evolutionary trend. There are both supersaturated (ie. normative quartz-bearing) and saturated (ie. normative olivine-bearing) tholeiites among samples, the former being more abundant than the latter.

The Parnaíba tholeiitic basalts and diabases can be divided into low- $\mathrm{TiO}_{2}(\mathrm{~L}-\mathrm{Ti})$ and high- $\mathrm{TiO}_{2}(\mathrm{H}-\mathrm{Ti})$ suites according to their $\mathrm{TiO}_{2}$ contents to similar evolutionary level $(\mathrm{MgO})$ with a boundary at $\mathrm{TiO}_{2}=2 \%$ (Fig. 5) and $\mathrm{Ti} / \mathrm{Y}=410$ (Fig. 6) as with many Continental Flood Basalt Provinces worldwide (Erlank et al. 1984, 1988, Peate 1997).

Neither the L-Ti nor the H-Ti studied samples bear primary basaltic compositions (e.g. Ni > 500 ppm; Cr $>1000$ ppm; $\mathrm{SiO}_{2}<50 \mathrm{wt}$ \%; magnesium number $0.68-$ 0.75; Roeder \& Emslie 1970, Wilson 1989) (Tab. 3). The two aforementioned suites cannot be related by evolutionary processes since a single parental magma could not give rise to such different $\mathrm{Ti} / \mathrm{Y}$ ratios and $\mathrm{TiO}_{2}$ contents for similar $\mathrm{MgO}$ values (Figs. 5 and 6). The small gap shown in both suites $(-4$ wt. $\%<\mathrm{MgO}<5.5$ wt. $\%)$ are most likely to be related to the somehow reduced amount of samples available for this study than to magma mixing processes. Even so, the petrogenetic investigations were carried on with great care to prevent possible biased interpretations and were mostly based on geochemical modelling.

\section{GEOCHEMICAL MODELLING OF EVOLUTIONARY PROCESSES}

The Rayleigh equation (Wood \& Fraser 1976) was used to test for relationships among basaltic suites in the study area by fractional crystallization. Results were then used in mass balance calculations in order to test for coherence with the degree of evolution based on the $\mathrm{MgO}$ content of samples. Additionally, assimilation and fractional crystallization (AFC) modelling (DePaolo 1981) was tried whenever fractional crystallization alone could not explain trace element variations within basaltic suites. As aforementioned, magma mixing or assimilation (without fractional crystallization) were not taken as possible differentiation processes 
Table 1. Major and trace elements analyses. n.d. = not detected. $\mathrm{Fe}_{2} \mathrm{O}_{3} \mathrm{t}$ is total iron. L.O.I. is the loss on ignition. Oxides in wt.\%. Trace elements in ppm.

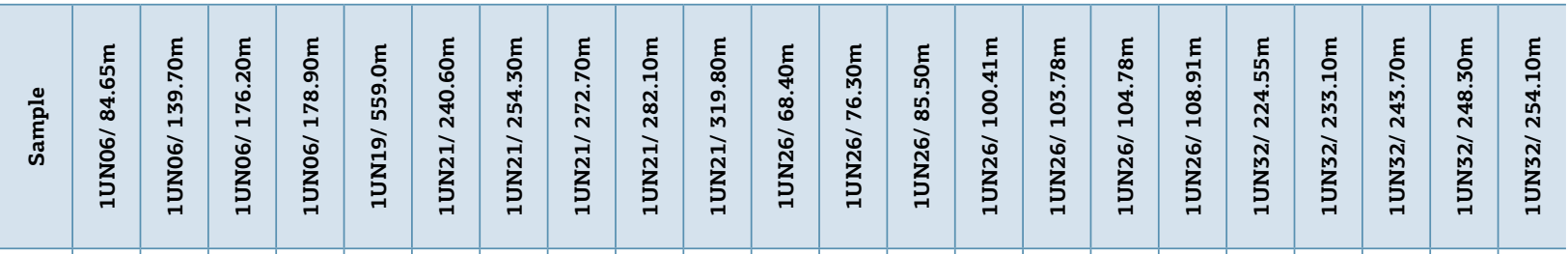

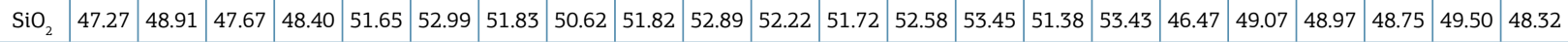
\begin{tabular}{l|l|l|l|l|l|l|l|l|l|l|l|l|l|l|l|l|l|l|l|l|l|l}
$\mathrm{TiO}_{2}$ & 2.37 & 2.28 & 2.08 & 2.22 & 1.45 & 1.43 & 1.47 & 1.40 & 1.35 & 1.51 & 1.55 & 1.69 & 1.72 & 1.93 & 2.87 & 2.59 & 2.91 & 2.27 & 2.24 & 2.28 & 2.32 & 2.21 \\
\hline
\end{tabular} \begin{tabular}{|l|l|l|l|l|l|l|l|l|l|l|l|l|l|l|l|l|l|l|l|l|l|l|l|l|l|l|}
$\mathrm{Al}_{2} \mathrm{O}_{3}$ & 14.04 & 13.60 & 13.91 & 13.40 & 13.63 & 13.90 & 14.08 & 13.88 & 14.20 & 13.90 & 13.30 & 13.25 & 13.55 & 13.00 & 11.97 & 11.93 & 12.42 & 13.79 & 13.29 & 13.46 & 13.44 & 13.39 \\
\hline
\end{tabular}

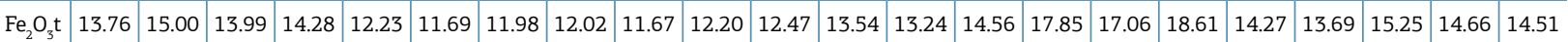

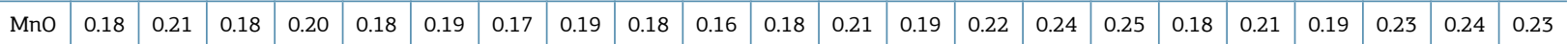

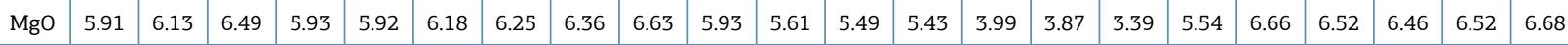
\begin{tabular}{|l|l|l|l|l|l|l|l|l|l|l|l|l|l|l|l|l|l|l|l|l|l|l|l|l|l|l|l|l|l|l|l|l|l}
$\mathrm{CaO}$ & 10.52 & 10.47 & 10.41 & 10.29 & 10.11 & 9.81 & 10.40 & 10.27 & 10.79 & 9.60 & 9.15 & 9.76 & 9.47 & 8.25 & 8.17 & 7.18 & 5.82 & 10.43 & 10.47 & 10.26 & 10.44 & 10.68 \\
\hline
\end{tabular}

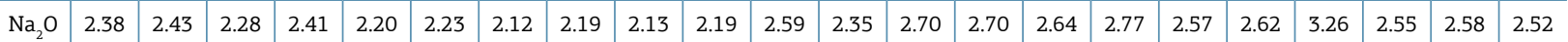
\begin{tabular}{|l|l|l|l|l|l|l|l|l|l|l|l|l|l|l|l|l|l|l|l|l|l|l|}
\hline $\mathrm{K}_{2} \mathrm{O}$ & 0.26 & 0.32 & 0.25 & 0.34 & 0.70 & 0.72 & 0.54 & 0.65 & 0.60 & 0.77 & 0.70 & 0.72 & 0.74 & 0.96 & 0.94 & 1.14 & 0.55 & 0.39 & 0.47 & 0.44 & 0.45 & 0.46 \\
\hline
\end{tabular}

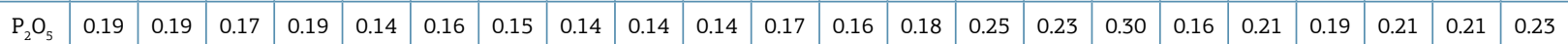

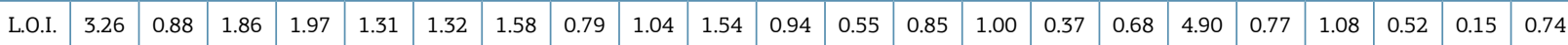

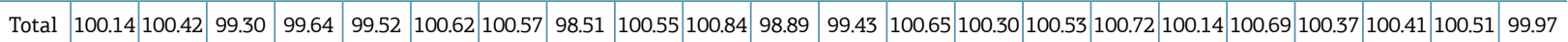

\begin{tabular}{|c|c|c|c|c|c|c|c|c|c|c|c|c|c|c|c|c|c|c|c|c|c|c|}
\hline $\mathrm{Ni}$ & 110 & 90 & 100 & 100 & 70 & 80 & 80 & 80 & 110 & 70 & 70 & 60 & 60 & 40 & 30 & 40 & 50 & 100 & 110 & 90 & 100 & 100 \\
\hline $\mathrm{Cr}$ & 130 & 110 & 130 & 110 & 60 & 40 & 70 & 60 & 100 & 50 & 20 & n.d. & n.d. & n.d. & n.d. & n.d. & n.d. & 130 & 120 & 120 & 120 & 140 \\
\hline Co & 56 & 57 & 65 & 67 & 77 & 64 & 60 & 82 & 90 & 70 & 53 & 56 & 60 & 78 & 60 & 59 & 76 & 70 & 99 & 81 & 72 & 79 \\
\hline Sc & 39 & 41 & 41 & 41 & 39 & 38 & 40 & 39 & 39 & 39 & 38 & 40 & 39 & 37 & 41 & 36 & 44 & 41 & 40 & 41 & 42 & 42 \\
\hline $\mathrm{V}$ & 470 & 483 & 466 & 473 & 347 & 368 & 346 & 368 & 361 & 349 & 398 & 392 & 434 & 434 & 647 & 596 & 815 & 535 & 525 & 547 & 549 & 521 \\
\hline $\mathrm{Rb}$ & 5 & 7 & 6 & 7 & 17 & 19 & 14 & 14 & 14 & 21 & 23 & 21 & 22 & 30 & 29 & 36 & 16 & 11 & 14 & 13 & 13 & 12 \\
\hline $\mathrm{Sr}$ & 256 & 252 & 269 & 352 & 197 & 202 & 208 & 224 & 229 & 247 & 181 & 187 & 192 & 197 & 181 & 185 & 200 & 208 & 209 & 194 & 197 & 198 \\
\hline $\mathrm{Ba}$ & 65 & 248 & 138 & 139 & 162 & 208 & 227 & 183 & 175 & 252 & 156 & 209 & 176 & 276 & 263 & 343 & 220 & 71 & 92 & 97 & 103 & 97 \\
\hline $\mathrm{Y}$ & 30 & 32 & 29 & 32 & 26 & 26 & 25 & 25 & 24 & 27 & 29 & 29 & 29 & 40 & 37 & 43 & 31 & 32 & 33 & 34 & 34 & 32 \\
\hline $\mathrm{Zr}$ & 146 & 153 & 131 & 149 & 119 & 116 & 116 & 101 & 99 & 131 & 125 & 133 & 120 & 170 & 199 & 211 & 149 & 140 & 139 & 144 & 145 & 131 \\
\hline $\mathrm{Nb}$ & 7 & 7 & 6 & 7 & 7 & 8 & 6 & 6 & 6 & 8 & 8 & 8 & 8 & 11 & 12 & 12 & 11 & 7 & 8 & 8 & 8 & 7 \\
\hline $\mathrm{La}$ & 8.63 & 8.93 & 7.94 & 8.98 & 11.5 & 12.2 & 11.2 & 10.9 & 10.1 & 12.8 & 14.7 & 12.6 & 13 & 18.9 & 17.8 & 22.5 & 14.1 & 10.5 & 11.1 & 77.6 & 18.1 & 9.95 \\
\hline $\mathrm{Ce}$ & 24.0 & 24.2 & 21.6 & 24.1 & 27.0 & 28.4 & 25.8 & 25.3 & 23.5 & 29.2 & 31.9 & 29.4 & 30.6 & 44.1 & 40.3 & 50.4 & 32.6 & 25.9 & 28.0 & 93.3 & 34.5 & 25.1 \\
\hline $\operatorname{Pr}$ & 3.70 & 3.69 & 3.23 & 3.67 & 3.61 & 3.71 & 3.41 & 3.48 & 3.24 & 4.01 & 4.07 & 3.99 & 4.09 & 5.86 & 5.43 & 6.61 & 4.40 & 3.84 & 4.11 & 3.92 & 3.96 & 3.70 \\
\hline $\mathrm{Nd}$ & 17.9 & 18.0 & 15.8 & 17.8 & 15.7 & 15.8 & 15.2 & 15.0 & 14.1 & 17.1 & 17.4 & $\mid \begin{array}{l}\mid 7.7 \\
\end{array}$ & 18.3 & 25.0 & 23.1 & 29.1 & 19.3 & 18.1 & 19.7 & 18.8 & 19.3 & 17.9 \\
\hline Sm & 5.34 & 5.44 & 5.10 & 5.22 & 4.33 & 4.38 & 4.12 & 4.21 & 3.74 & 4.57 & 4.75 & 4.70 & 4.77 & 6.65 & 6.06 & 7.26 & 5.32 & 5.26 & 5.82 & 5.90 & 5.63 & 5.28 \\
\hline $\mathrm{Eu}$ & 1.91 & 1.89 & 1.67 & 1.82 & 1.46 & 1.45 & 1.39 & 1.39 & 1.32 & 1.45 & 1.60 & 1.62 & 1.57 & 2.15 & 1.92 & 2.20 & 1.85 & 1.91 & 1.97 & 1.96 & 2.07 & 1.87 \\
\hline $\mathrm{Gd}$ & 6.00 & 6.06 & 5.46 & 5.96 & 4.70 & 4.69 & 4.60 & 4.54 & 4.22 & 4.65 & 5.21 & 5.25 & 5.51 & 7.27 & 6.86 & 7.81 & 5.47 & 6.00 & 6.46 & 6.30 & 6.52 & 5.98 \\
\hline $\mathrm{Tb}$ & 1.06 & 1.05 & 0.94 & 1.03 & 0.81 & 0.83 & 0.79 & 0.77 & 0.73 & 0.83 & 0.90 & 0.86 & 0.90 & 1.23 & 1.13 & 1.35 & 1.00 & 1.02 & 1.10 & 1.10 & 1.09 & 1.04 \\
\hline Dy & 6.23 & 6.34 & 5.65 & 6.20 & 5.04 & 4.98 & 4.79 & 4.76 & 4.47 & 5.13 & 5.41 & 5.52 & 5.49 & 7.65 & 6.83 & 8.24 & 6.16 & 6.19 & 6.62 & 6.62 & 6.57 & 6.32 \\
\hline Ho & 1.21 & 1.20 & 1.08 & 1.20 & 0.99 & 0.97 & 0.95 & 0.94 & 0.88 & 1.02 & 1.09 & 1.11 & 1.10 & 1.55 & 1.39 & 1.65 & 1.23 & 1.24 & 1.26 & 1.30 & 1.35 & 1.24 \\
\hline Er & 3.32 & 3.43 & 3.04 & 3.36 & 2.74 & 2.74 & 2.66 & 2.68 & 2.50 & 2.87 & 3.19 & 3.19 & 3.07 & 4.42 & 3.90 & 4.72 & 3.41 & 3.49 & 3.52 & 3.54 & 3.53 & 3.45 \\
\hline $\mathrm{Tm}$ & 0.463 & 0.490 & 0.431 & 0.479 & 0.401 & 0.395 & 0.386 & 0.377 & 0.362 & 0.410 & 0.455 & 0.464 & 0.453 & 0.636 & 0.560 & 0.682 & 0.498 & 0.489 & 0.489 & 0.514 & 0.493 & 0.469 \\
\hline $\mathrm{Yb}$ & 2.76 & 3.09 & 2.61 & 2.99 & 2.60 & 2.53 & 2.44 & 2.44 & 2.29 & 2.50 & 2.91 & 2.95 & 2.97 & 4.06 & 3.56 & 4.45 & 3.27 & 3.14 & 3.03 & 3.26 & 3.19 & 3.01 \\
\hline $\mathrm{Lu}$ & 0.416 & 0.463 & 0.395 & 0.451 & 0.398 & 0.392 & 0.366 & 0.380 & 0.354 & 0.384 & 0.442 & 0.446 & 0.447 & 0.623 & 0.552 & 0.678 & 0.515 & 0.474 & 0.460 & 0.484 & 0.500 & 0.459 \\
\hline $\mathrm{Hf}$ & 3.6 & 3.6 & 3.2 & 3.7 & 3.1 & 3.1 & 3.0 & 2.6 & 2.9 & 3.1 & 3.4 & 3.5 & 3.2 & 4.9 & 4.8 & 5.7 & 3.5 & 3.8 & 3.4 & 3.9 & 3.8 & 3.5 \\
\hline $\mathrm{Pb}$ & n.d. & n.d. & n.d. & n.d. & n.d. & n.d. & n.d. & n.d. & n.d. & n.d. & n.d. & n.d. & n.d. & n.d. & n.d. & 8 & n.d. & n.d. & n.d. & n.d. & 15 & n.d. \\
\hline Th & 0.71 & 0.89 & 0.85 & 0.90 & 2.15 & 2.37 & 2.00 & 1.96 & 1.81 & 2.52 & 2.46 & 2.28 & 2.36 & 3.63 & 3.21 & 4.38 & 2.40 & 0.97 & 1.21 & 1.04 & 1.05 & 0.89 \\
\hline U & 0.21 & 0.24 & 0.23 & 0.23 & 0.50 & 0.58 & 0.47 & 0.49 & 0.44 & 0.57 & 0.62 & 0.58 & 0.57 & 0.87 & 0.80 & 0.99 & 0.58 & 0.25 & 0.54 & 0.29 & 0.27 & 0.24 \\
\hline
\end{tabular}


since the small compositional gap has been interpreted as resulting from constrained sampling.

Modelling was mostly performed taking into consideration a fractionating assemblage of olivine (10 \pm 2 vol.\%) and augite ( $90 \pm 2$ vol.\%), according to the phenocrysts contents of the studied samples. Extract compositions for mass balance calculations varied from $\mathrm{MgO}=10$ to 15 wt. $\%$, considering olivine compositions with $20 \mathrm{wt} . \%$ $<\mathrm{MgO}<25$ wt. $\%$ and augite compositions with $10 \mathrm{wt} . \%$ $<\mathrm{MgO}<15$ wt. $\%$, according to the $\mathrm{MgO}$ compositions of typical basaltic parental liquids (e.g. Piccirillo \& Melfi 1988). The crystal-liquid partition coefficients used in modelling were those compiled by Rollinson (1993) unless otherwise indicated. Tests were also made for fractionating assemblages with different amounts of plagioclase although the disequilibrium textures described for this mineral indicate that it is likely to represent either antecrysts or xenocrysts (Fig. 2).

The L-Ti and H-Ti parental and most evolved compositions for the whole study area are presented in Tab. 3. Since the two suites cannot be related by differentiation processes, modelling will be performed separately.

Samples $1 \mathrm{UN} 21 / 282.10 \mathrm{~m}(\mathrm{MgO}=6.63 \mathrm{wt} . \%$ and $\left.\mathrm{La} / \mathrm{Yb}_{\mathrm{n}}=2.9\right)$ and $1 \mathrm{UN} 26 / 100.41 \mathrm{~m}(\mathrm{MgO}=3.99$ wt. $\%$ and $\mathrm{La} / \mathrm{Yb}_{\mathrm{n}}=3.1$ ) represent respectively the parental and most evolved samples of the L-Ti suite. Modelling using the Rayleigh equation shows that the $\mathrm{La} / \mathrm{Yb}$ ratio variation $(6 \%)$ between parental and evolved liquids could be achieved by $13 \%$ fractional crystallization of olivine: augite in the proportion of 10:90 and bulk partition coefficients (D) such as $\mathrm{D}_{\mathrm{La}}=0.051$ and $\mathrm{D}_{\mathrm{Yb}}=0.493$. Mass balance calculations showed that such amount of fractional crystallization would require a parental composition with $\mathrm{MgO}=$ $7-10 \%$ and an extract with unrealistic $\mathrm{MgO}=42 \%$ to generate the evolved liquid $(\mathrm{MgO}=3.99 \mathrm{wt} . \%)$ within the L-Ti suite. Fractionating assemblages with $10 \%$ olivine and different proportions of augite and plagioclase (from 80:10 to 40:60) were also considered in modelling. Results showed that minimum (10\%) and maximum (60\%) amounts of plagioclase would require $15 \%$ and $60 \%$ fractional crystallization to cope with the $\mathrm{La} / \mathrm{Yb}$ ratio variation within the low- $\mathrm{TiO}_{2}$ basaltic suite (for $\mathrm{D}_{\mathrm{La}}=0.071-0.138$ and $\mathrm{D}_{\mathrm{Yb}}=$ $0.444-0.201)$. Nevertheless, mass balance calculations showed that it would be necessary 30 and $90 \%$ fractional crystallization to explain $\mathrm{MgO}$ variations between parental and evolved compositions of the low- $\mathrm{TiO}_{2}$ samples for extracts with such amounts of plagioclase. Likewise, AFC modelling cannot explain the $\mathrm{La}$ and $\mathrm{Yb}$ variations within the L-Ti suite (Fig. 7).

Similar geochemical modelling was performed for the $\mathrm{H}$-Ti suite in the study area. Samples $1 \mathrm{UN} 32 / 254.10 \mathrm{~m}$ $\left(\mathrm{MgO}=6.68 \mathrm{wt} . \%\right.$ and $\left.\mathrm{La} / \mathrm{Yb}_{\mathrm{n}}=2.2\right)$ and $1 \mathrm{UN} 26 / 104.78 \mathrm{~m}$
$\left(\mathrm{MgO}=3.39\right.$ wt. $\%$ and $\left.\mathrm{La} / \mathrm{Yb}_{\mathrm{n}}=3.4\right)$ represent respectively the parental and most evolved samples of the H-Ti suite. Modelling using the Rayleigh equation shows that the La/ $\mathrm{Yb}$ ratio variation (53\%) between parental and evolved liquids could be achieved by $-80 \%$ fractional crystallization, keeping with the same fractionating assemblage (olivine:augite $=10: 90$ ) and $\mathrm{D}$ values used on modelling the $\mathrm{L}$-Ti suite. However, $\mathrm{MgO}$ differences between parental and most evolved compositions within the H-Ti suite would require only $-50 \%$ fractional crystallization. Crosschecking of the $\mathrm{La} / \mathrm{Yb}$ ratio variation and $\mathrm{MgO}$ variation using the Rayleigh equation and mass balance calculations was not consistent using different amounts (10 to 60\%) of plagioclase in the fractionating assemblage in models. Likewise, AFC modelling cannot explain the Ti and $\mathrm{Y}$ variations within the H-Ti suite (Fig. 8). So far, the results showed that there must be more than one $\mathrm{H}$-Ti suite as well as more than one L-Ti suite in the study area.

The presence of chilled margins between the magmatic rocks and their enclosing sedimentary rocks in the studied boreholes are consistent with the intrusive nature of the former. As such, the studied samples are likely to represent diabase sills, which is in agreement with the prevalent intrusive nature of the magmatic rocks within the Sardinha Formation eastwards the Parnaíba basin based on previous works (eg. Vaz et al. 2007). The existence of several L-Ti and $\mathrm{H}$-Ti in the study area as depicted by the geochemical modelling is somehow expected considering that, the Parnaíba diabases are predominantly saucer-shaped (Porto \& Pereira 2014) and that, the emplacement mechanisms of such intrusions would prevent them to spread over large areas (Hansen 2015).

Different L-Ti and H-Ti suites can be discriminated by comparing trace element ratios of samples with the same degree of evolution (ie., same $\mathrm{MgO}$ contents). For instance, the L-Ti samples 1 UN21/319.80m and 1 UN19/559.00m were collected from borelohes, which are about $200 \mathrm{~km}$ apart from each other. These samples have the same $\mathrm{MgO}$ content (respectively, 5.93 wt. \% and 5.92 wt.\%) but rather different $\mathrm{La} / \mathrm{Yb}_{\mathrm{n}}$ (respectively, 3.4 and 3.0) and could clearly not have evolved from the same parental magma. As such, they constitute two different L-Ti suites in the study area.

Boreholes 1UN06 and 1UN32 are about $20 \mathrm{~km}$ apart and gave only $\mathrm{H}$-Ti samples. Samples from the top and base of borehole $1 \mathrm{UN} 32$ have the same $\mathrm{MgO}$ contents $\left(\sim 6.6\right.$ wt.\%) and $\mathrm{La} / \mathrm{Yb}_{\mathrm{n}}$ ratios (2.2) which, in turn, is the same (considering an analytical error of \pm 0.1 ) of sample 1UN06/84.65m whose $\mathrm{MgO}=5.91$ wt. $\%$. Cogenetic liquids evolved from the same parental magma cannot reach the same $\mathrm{La} / \mathrm{Yb}_{\mathrm{n}}$ ratios for different degrees of evolution (ie. different $\mathrm{MgO}$ contents). Variations of the $\mathrm{La} / \mathrm{Yb}_{\mathrm{n}}$ ratio are 
most dependent upon the fractionating assemblage. If only olivine and clinopyroxene fractionate, as presented in previous geochemical models, then the $\mathrm{La} / \mathrm{Yb}$, ratio will not vary too much. However, as demonstrated in the models presented previously, including plagioclase in the fractionating assemblage does not change the results of the modelling because the $\mathrm{Kd}_{\mathrm{La}}$ value of plagioclase is greater than those of clinopyroxene and olivine but $\mathrm{Kd}_{\mathrm{Yb}}$ values are smaller than those same mafic phases, balancing the $\mathrm{La} / \mathrm{Yb}_{\mathrm{n}}$ ratio variation. Similarly, crystallization and contamination (AFC) can vary from place to place for liquids derived from the same parental magma only in cases different compositions of contaminants are taken in consideration. However, the AFC modelling previously performed assumed a rather invariable

A

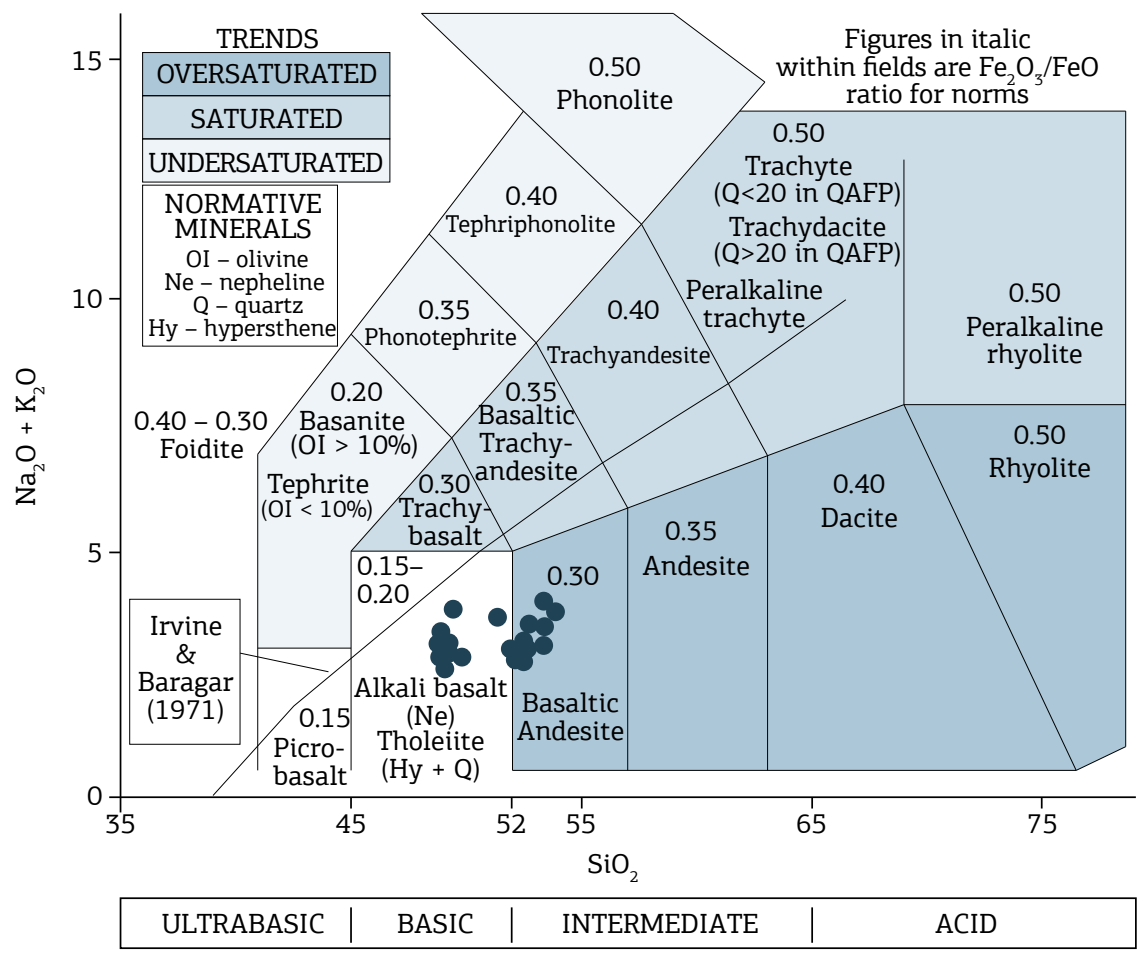

B

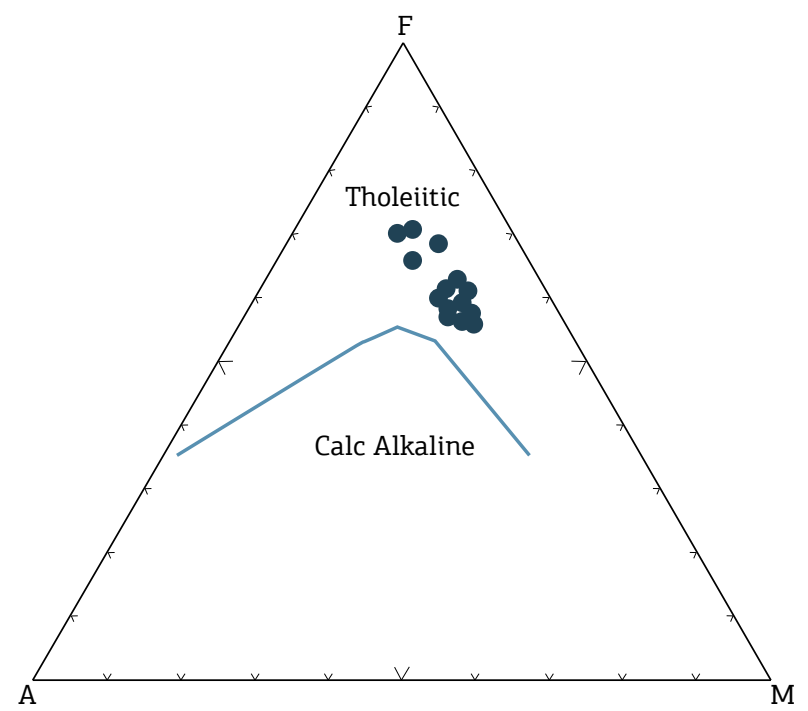

Figure 4. The total alkalis versus silica (TAS; in wt.\%) discrimination and classification diagram (A) and the AFM $\left(\mathrm{A}=\mathrm{Na}_{2} \mathrm{O}+\mathrm{K}_{2} \mathrm{O}, \mathrm{F}=\mathrm{FeO}+0.8998 \mathrm{Fe}_{2} \mathrm{O}_{3}, \mathrm{M}=\mathrm{MgO}\right.$, in wt.\%) diagram (B) for the studied samples (LeBas et al. 1986, LeMaitre 2002). Curves are from Irvine \& Baragar (1971). Data recalculated to $100 \%$ on a volatile-free basis. The $\mathrm{Fe}_{2} \mathrm{O}_{3} / \mathrm{FeO}$ ratios for CIPW norm calculations (Middlemost 1989) are shown in the TAS classification fields. 
composition of the country rocks for the magma chambers as the simplest approach. Overall, it seems that there are more than one $\mathrm{H}-\mathrm{Ti}$ suite in the study area, represented at least in boreholes 1UN06 and 1UN32.

Geochemical modelling using the Rayleigh equation showed that $\mathrm{MgO}(5,91 \%<\mathrm{MgO}<6,49 \%)$ and $\mathrm{La} / \mathrm{Yb}_{\mathrm{n}}(2,0 \pm 0,1)$ variations in borehole $1 \mathrm{UN} 06$ could be explained by $7 \%$ of fractional crystallization with augite and olivine in the proportions of 90:10, an extract with $\mathrm{MgO}=14.20 \mathrm{wt} . \%$, and $\mathrm{D}_{\mathrm{La}}=0.051$ and $\mathrm{D}_{\mathrm{Yb}}=0.493$. On the other hand, differentiation processes associated with borehole $1 \mathrm{UN} 32$ seem to be more complex. Samples collected along a 30m-thick, discontinuous section have rather similar $\mathrm{MgO}$ contents (6.46 wt. $\%<\mathrm{MgO}$ $<6.68$ wt.\%,) but different La/Yb ratios (Fig. 9). These variations preclude fractional crystallization and AFC as possible differentiation processes. It should be noted that the REE patterns of the five samples collected in borehole 1UN32 are similar as expected from their narrow range of $\mathrm{MgO}$ (Fig. 10). However, the contents of $\mathrm{La}$ and $\mathrm{Ce}$ are very discrepant when compared to other REE, which, in turn, explain their variable

Table 2. Maximum, minimum, average and standard deviation values of CIPW norm of the studied samples. All values are expressed in wt.\%. Iron ratios for calculations according to Middlemost (1989).

\begin{tabular}{l|c|c|c|c}
\hline $\begin{array}{l}\text { Normative } \\
\text { minerals }\end{array}$ & Maximum & Minimum & Average & $\begin{array}{c}\text { Standard } \\
\text { deviation }\end{array}$ \\
\hline Nepheline & 0.00 & 0.00 & 0.00 & 0.00 \\
\hline Hypersthene & 29.76 & 7.16 & 17.44 & 4.01 \\
\hline Olivine & 7.03 & 0.00 & 0.38 & 1.48 \\
\hline Quartz & 11.86 & 0.00 & 4.49 & 3.58 \\
\hline Diopside & 25.44 & 6.32 & 19.33 & 3.69 \\
\hline Orthoclase & 6.80 & 1.54 & 3.60 & 1.37 \\
\hline Plagioclase & 49.06 & 40.66 & 45.72 & 1.98 \\
\hline Apatite & 0.70 & 0.32 & 0.44 & 0.09 \\
\hline Ilmenite & 5.91 & 2.60 & 3.90 & 0.93 \\
\hline Magnetite & 7.51 & 3.44 & 4.71 & 1.01 \\
\hline
\end{tabular}

$\mathrm{La} / \mathrm{Yb}$ ratios. Those two light- $\mathrm{REE}$ are prone to mobilization by fluids (e.g. Pearce 1983, Humphries 1984, Hoyle et al. 1984, Tsay et al. 2014) which makes reasonable to test for in situ (ie. in-conduit) contamination of a single intrusion by percolating fluids from the interbedded sedimentary rocks.

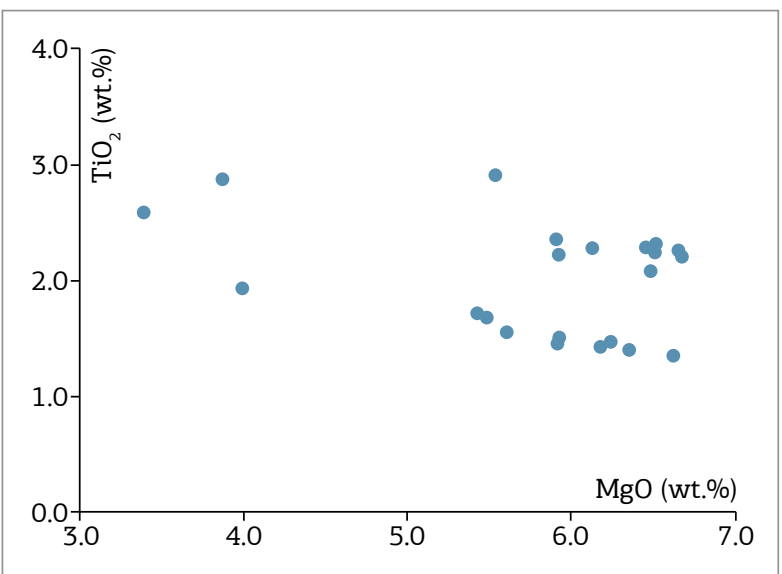

Figure 5. Variation diagram for $\mathrm{TiO}_{2}$ for the studied samples showing two different evolutionary trends (low- and high- $\mathrm{TiO}_{2}$ suites) with a boundary at $\mathrm{TiO}_{2}=2.00 \mathrm{wt} . \%$.

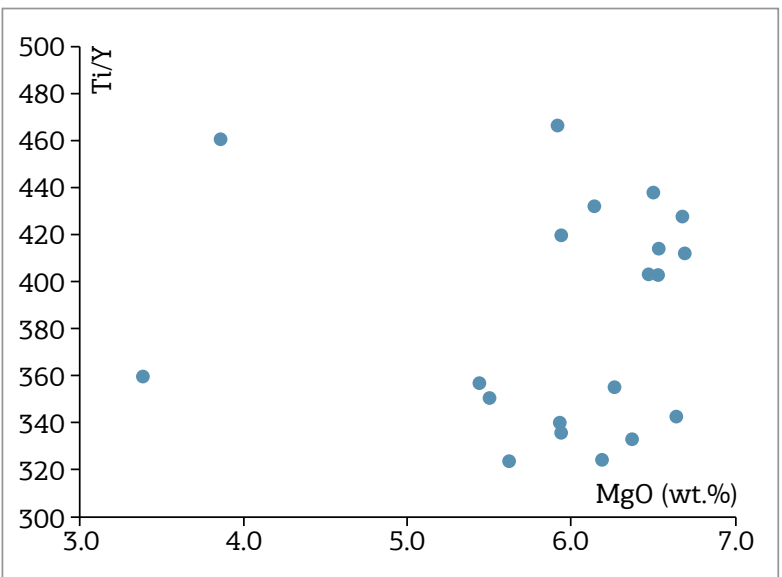

Figure 6. Variation diagram for $\mathrm{Ti} / \mathrm{Y}$ for the studied samples showing two different evolutionary trends (low- and high- $\mathrm{TiO}_{2}$ suites) with a boundary at $\mathrm{Ti} / \mathrm{Y}=410$.

Table 3. Representative compositions of the parental and the most evolved liquids of the low- $\mathrm{TiO}{ }_{2}(\mathrm{~L}-\mathrm{Ti})$ and high- $\mathrm{TiO}_{2}(\mathrm{H}-\mathrm{Ti})$ suites in the study area. n.d. = not detected.

\begin{tabular}{l|c|c|c|c|c}
\hline Composition & Sample & $\mathbf{S i O}_{2}$ (wt.\%) & MgO (wt.\%) & Ni (ppm) & $\mathbf{C r}$ (ppm) \\
\hline Parental L-Ti & 1UN21/282.10m & 51.82 & 6.63 & 110 & 100 \\
\hline Evolved L-Ti & $1 \mathrm{UN26/100.41m}$ & 53.45 & 3.99 & 40 & n.d. \\
\hline Parental H-Ti & $1 \mathrm{UN} 32 / 254.10 \mathrm{~m}$ & 48.32 & 6.68 & 100 & 140 \\
\hline Evolved H-Ti & $1 \mathrm{UN} 26 / 104.78 \mathrm{~m}$ & 53.43 & 3.39 & 40 & n.d. \\
\hline
\end{tabular}


Fluid contamination is preferred to rock contamination because there is no appropriate eutectic composition in the sandstone country rocks that could cope with the extreme $\mathrm{La}$ and Ce fractionation compared to other REE.

As a first approach, the in-conduit assimilation can be modelled as a binary mixing process between the fluid and magma using the equations shown in Faure (1986). The major drawback in the modelling refers to the composition of the contaminating fluid. Thus, calculations were made for fluids with $\mathrm{La} / \mathrm{Yb}$ ratios varying from 10 to 50 in order to produce the $\mathrm{La} / \mathrm{Yb}$ ratios of samples $1 \mathrm{UN} 32 / 233.90 \mathrm{~m}$ (3.7),

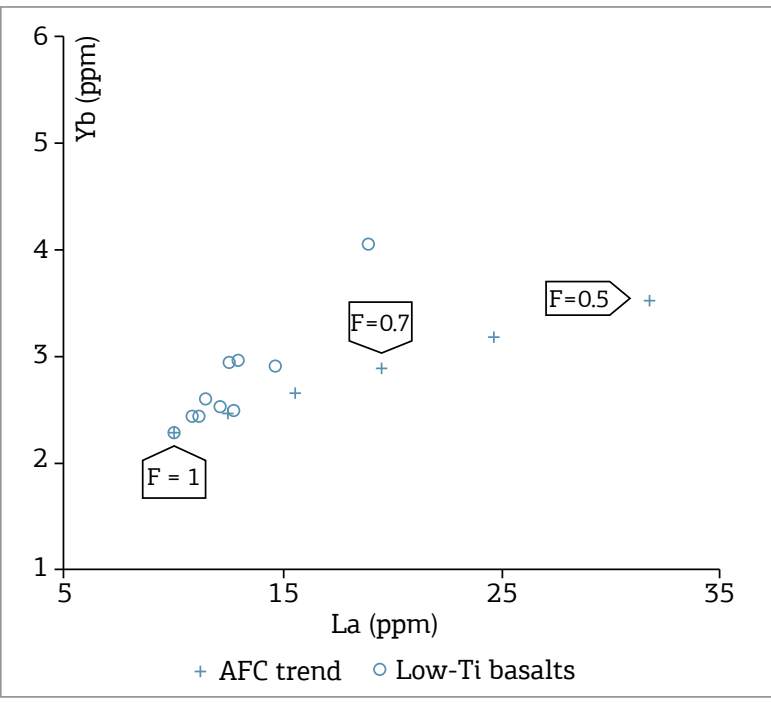

Figure 7. La versus $\mathrm{Yb}$ diagram showing an AFC curve at $F=0.1$ intervals up to $F=0.5$. The $\mathrm{L}$ - $\mathrm{Ti}$ samples are shown. Other parameters used in modelling were: $\mathrm{D}_{\mathrm{La}}=0.051 ; \mathrm{D}_{\mathrm{Yb}}=0.493 ; \mathrm{r}=0.3$. Upper crust composition from Taylor \& McLennan (1981).

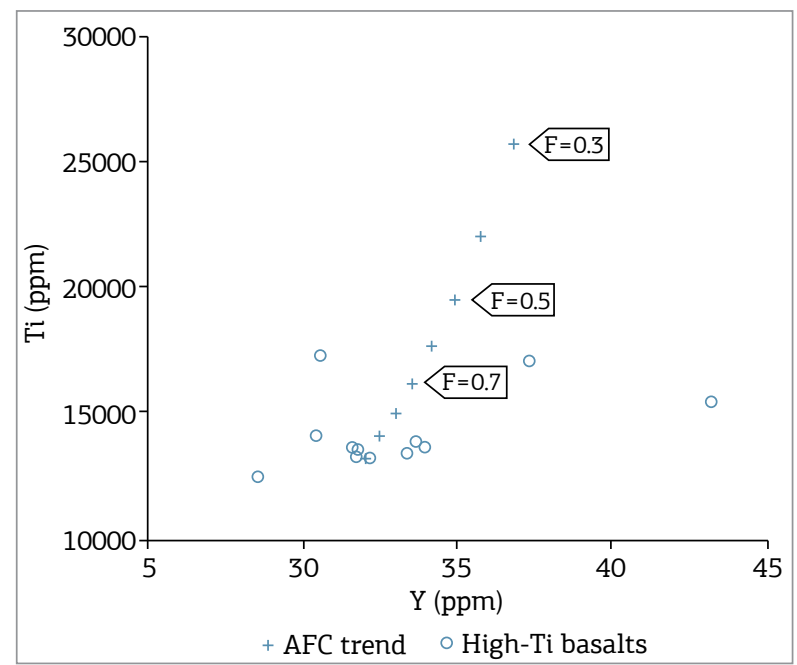

Figure 8. Y versus $\mathrm{Ti}$ diagram showing an AFC curve at $F=0.1$ intervals up to $F=0.7$. The $\mathrm{H}-\mathrm{Ti}$ samples are shown. Other parameters used in modelling are those in Figure 7.
1UN32/248.30m (5.7), and 1UN32/243.70m (23.8) located within the contamination zone (Fig. 11). Results showed that fluids with $\mathrm{La} / \mathrm{Yb}<20$ cannot give rise to the $\mathrm{La} / \mathrm{Yb}$ ratio (23.8) of contaminated magma represented by sample $1 \mathrm{UN} 32 / 243.70 \mathrm{~m}$. Thus, that is the minimum value (20) of contaminant fluids needed for the contamination to take place. The very high La/Yb ratio of sample $1 \mathrm{UN} 32 / 243.70 \mathrm{~m}$ could only be achieved by contamination with $71 \%$ of fluids. The widespread venulation within the contamination zone gives support to the fluid contamination hypothesis (Fig. 12).

Borehole 1UN21 is located southwards the study area (Fig. 1) and comprises only L-Ti tholeiites (Tab. 1). The MgO variation between parental $(1 \mathrm{UN} 21 / 282.10 \mathrm{~m} ; \mathrm{MgO}=6.63$ wt.) and most evolved $1 \mathrm{UN} 21 / 319.80 \mathrm{~m} ; \mathrm{MgO}=5.93$ wt.\%) compositions cannot be correlated with their large variations

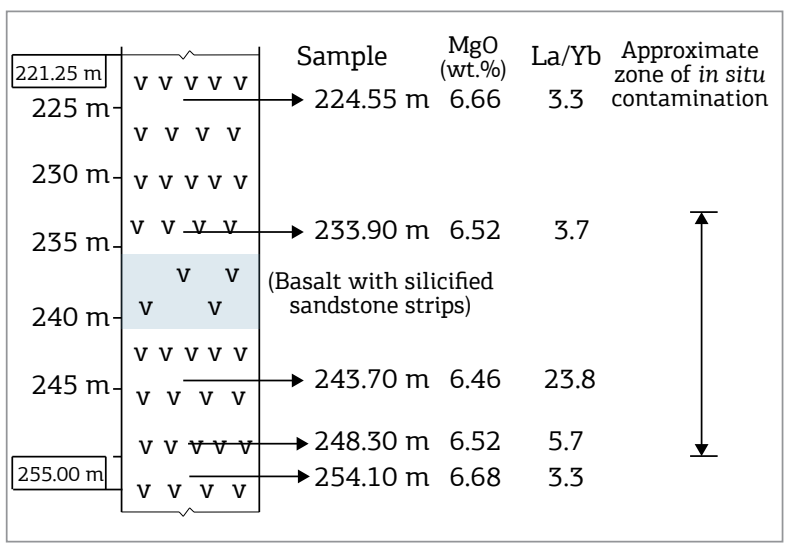

Figure 9. Schematic sampled section of borehole 1UN32. $\mathrm{MgO}$ (wt.\%) and $\mathrm{La} / \mathrm{Yb}$ ratios are indicated. The approximate in situ contamination zone was estimated by the anomalously values of $\mathrm{La} / \mathrm{Yb}$ ratios compared to those of the top and the base of the intrusion.

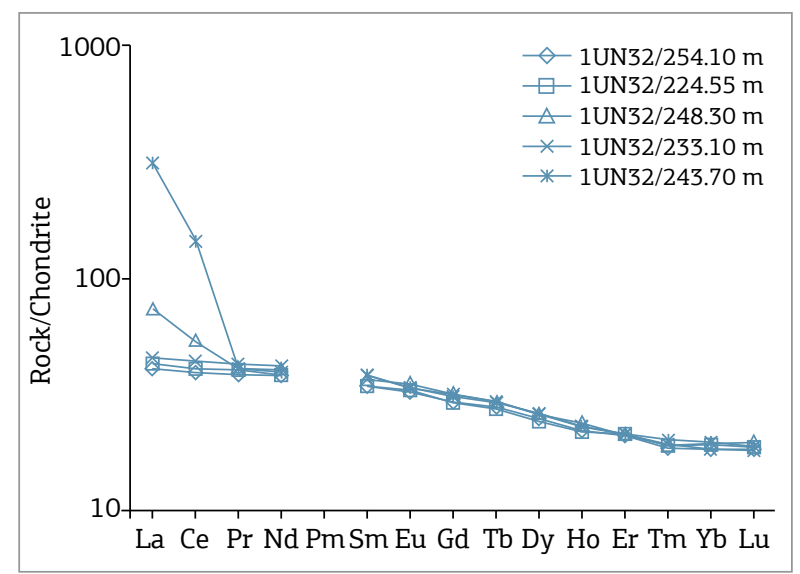

Figure 10. Chondrite-normalized REE diagram for samples from borehole 1UN32. Normalization factors from Evensen et al. (1978). 
of $\mathrm{La} / \mathrm{Yb}_{\mathrm{n}}$ ratios $(-16 \%)$ by fractional crystallization. Instead, AFC seems to explain the variation of some trace elements (eg. Y, Ti, Zr, La, and $\mathrm{Yb}$ ) within this L-Ti suite. Results of AFC modelling (Fig. 13) showed that such variations can be attributed to $10 \%$ to $13 \%$ fractional cristallization of olivine (10 vol.\%) and augite (90 vol.\%) concomitant to assimilation of upper crust rocks (Taylor \& McLennan 1981) at shallow-level magma chambers $(r=0.3)$.

Borehole 1UN26 is located northwards the study area (Fig. 1) and comprises both L-Ti tholeiites at its top ( -69 to $100 \mathrm{~m}$ ) and H-Ti tholeiites at its base (> $103 \mathrm{~m}$ ) (Tab. 1). Drilling was stopped at $-108 \mathrm{~m}$ and textural variations indicate that the intrusion may be at least $60 \mathrm{~m}$ thick. In the lowermost $\mathrm{H}-\mathrm{Ti}$ section of the borehole, $\mathrm{La} / \mathrm{Yb}_{\mathrm{n}}$ and $\mathrm{MgO}$ variations can be explained by $31 \%$ of fractional crystallization solely of augite, giving rise to an extract with $\mathrm{MgO}=10 \mathrm{wt} . \%$. In the uppermost L-Ti section of the borehole, the $\mathrm{La} / \mathrm{Yb}_{n}$ ratios decrease (from 3.4 to 3.1) with decreasing $\mathrm{MgO}$ contents (from 5.61 to 3.99 wt.\%) which is not in agreement with the greater incompatibility of La compared to $\mathrm{Yb}$ during the fractionation of olivine and/or augite and/or plagioclase. The same applies for AFC taking place in shallow-level magma chambers with La-rich contaminants. However, with the exception of sample $1 \mathrm{UN} 26 / 68.40 \mathrm{~m}$, located at the contact with the overlain sandstones, the $\mathrm{La} / \mathrm{Yb}$, ratios of the other L-Ti tholeiites in borehole 1 UN26 could be explained by $20 \%$ fractional crystallization of olivine (12\%) and augite (88\%). The $\mathrm{MgO}$ variation of these samples can also be explained by the same amount of fractional crystallization involving an extract with $\mathrm{MgO}=11.50 \mathrm{wt}$.\%. It should be noted that the L-Ti samples of borehole 1UN26 cannot be related with those of boreholes $1 \mathrm{UN} 19$ and 1UN21 due to incongruent $\mathrm{La} / \mathrm{Yb}_{n}$ variations among parental and most evolved compositions found in these three boreholes.

The REE patterns of the uppermost 1UN26 L-Ti sample at the contact with the overlain sandstone and of sample 1UN26/76.30m located about $8 \mathrm{~m}$ below (Fig. 14) show the same anomalously fractionation of La and Ce depicted by the fluid-contaminated samples in borehole 1UN32. Binary mixing modelling showed that $9 \%$ contamination by fluids with $\mathrm{La} / \mathrm{Yb}_{\mathrm{n}}=20$ could generate the $\mathrm{La} / \mathrm{Yb}_{\mathrm{n}}$ ratio (3.4) of sample $1 \mathrm{UN} 26 / 68.40 \mathrm{~m}$ in contact with overlain sandstones. Similarly, 5\%, 15\%, and 30\% contamination would require contaminating fluids with $\mathrm{La} / \mathrm{Yb}_{\mathrm{n}}$ ratios of 40, 6.7 and 13.4 , respectively. If the amount of contamination can be directly related to the volume of veins, then the scarce occurrence of the latter indicates that the contaminant fluid would have $\mathrm{La} / \mathrm{Yb}_{\mathrm{n}}-40$ as a maximum value.

In summary, the results of geochemical modelling performed in this section to investigate possible differentiation processes involving the Parnaíba tholeiites showed that there are more than one L-Ti and than one $\mathrm{H}$-Ti suites in the study area. Fractional crystallization and AFC can explain trace element variations within most suites but in-conduit, fluid-related contamination took place locally. The results point to various shallow-level magma chambers underneath the Parnaíba basin in the Mesozoic as opposed to few, large, long-living reservoirs. Such reasonably small magma chambers may have fed sills and dykes intruded into the overlain sedimentary sequence taking advantage of a well-fractured upper crust built over possible reactivation processes throughout geological time. The existence of various magma chambers may have contributed to increase the geothermal gradient in the basin area at the time of magmatism.

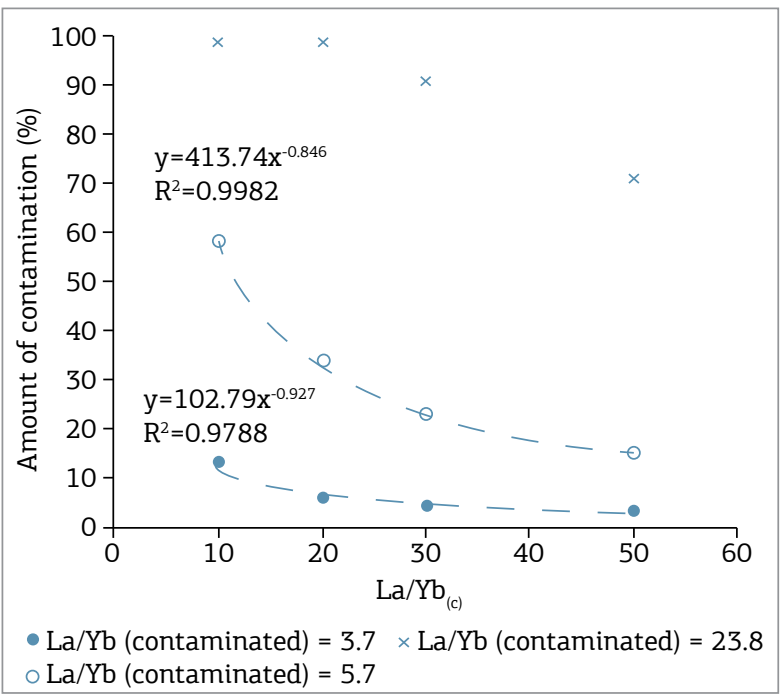

Figure 11. Diagram showing the relation of the amount of contamination (or the amount of contaminant fluid) and the $\mathrm{La} / \mathrm{Yb}_{\text {(c) }}$ ratio of fluids to produce the contaminated magmas of borehole 1 UN32.

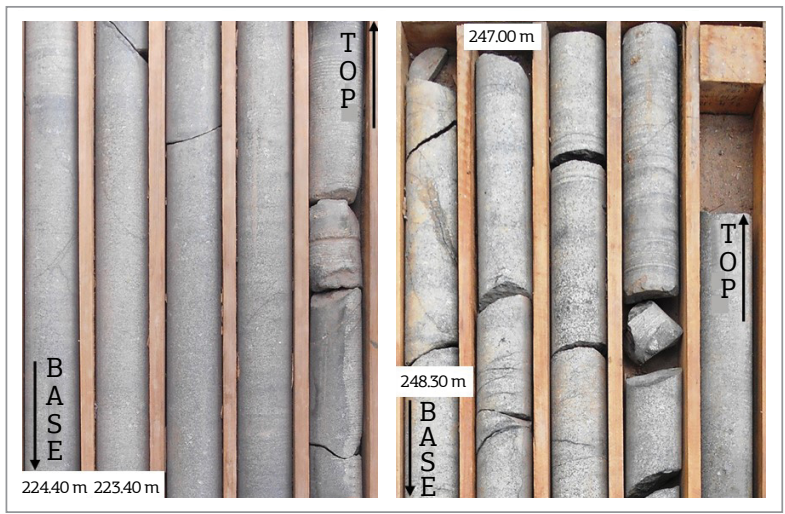

Figure 12. Photograph of sections of borehole 1UN32 outside (A) and inside (B) the contamination zone. The latter bears a greater volume of veins than the former as depicted by its whitish, more fractured features. 


\section{MANTLE SOURCES DISCRIMINATION AND MODELLING OF PARTIAL MELTING PROCESSES}

Representative samples of parental magmas of the L-Ti and H-Ti discriminated before are shown on Table 4. The REE patterns of these samples display $\mathrm{La} / \mathrm{Yb}_{\mathrm{n}}$ and $\mathrm{La} / \mathrm{Nb}_{\mathrm{n}}$ ratios greater than unity (Fig. 15), pointing to at least a contribution from enriched mantle sources on the generation of the L-Ti and H-Ti suites in the study area likely to be related with the subcontinental lithospheric mantle (SCLM).

Geochemical modelling was performed to put constraints on partial melting processes associated with the Parnaíba tholeiites. The equation of modal batch partial melting (Wood \& Fraser 1976) was used in the modelling and bulk partition coefficients were calculated with data compiled by Rollinson (1993) unless otherwise indicated. Residual mantle mineralogy was taken from Maaløe \& Aoki (1977) with aluminium-rich phases ranging from 1 to 5 vol.\%.

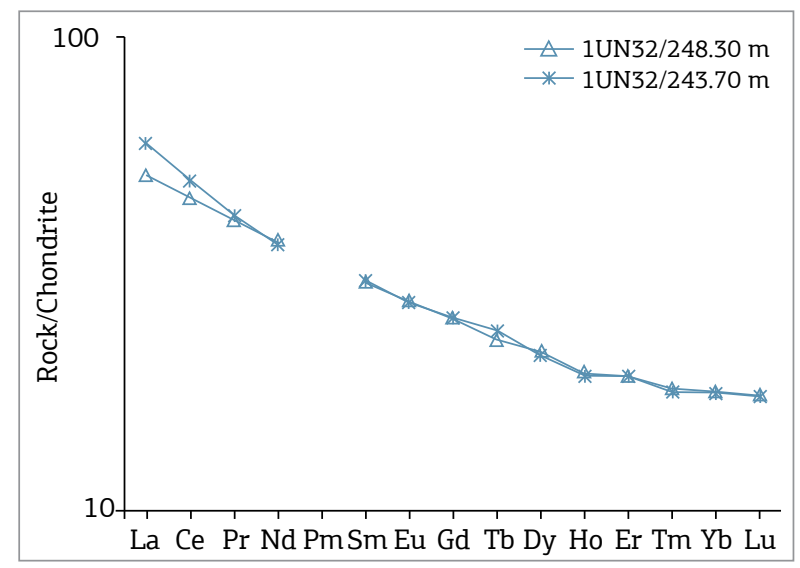

Figure 14. Chondrite-normalized REE diagram for samples from borehole 1UN26. Normalization factors from Evensen et al. (1978).
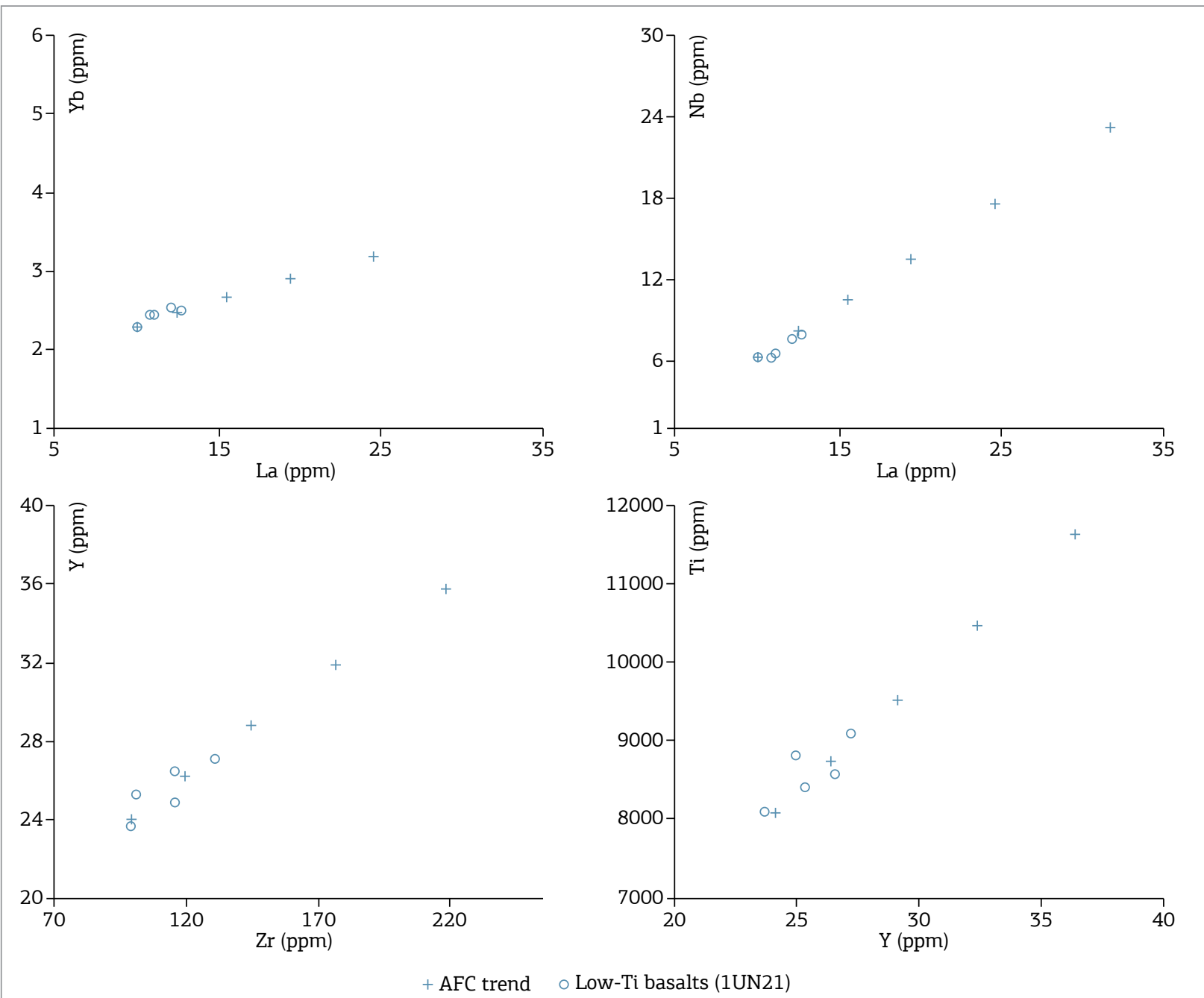

Figure 13. Bivariate diagrams with AFC curves for $\mathrm{F}=0.1$ intervals. The L-Ti tholeiites of borehole 1 UN2 1 are shown. Partition coefficients $\left(\mathrm{K}_{\mathrm{d}}\right)$ from Rollinson (1993), with the exception of Ti, Y, and $\mathrm{Zr}$ (Johnson 1998). 
Boreholes 1UN06 and 1UN32 comprise H-Ti suites and are about $20 \mathrm{~km}$ apart and modelling was performed to test for the hypothesis of their parental compositions being related to different degrees of partial melting from the same mantle source. The patterns of these samples in a chondrite-normalized multielemental diagram (Fig. 16) show the typical $\mathrm{Nb}$ negative anomaly of continental flood basalts (Peate 1997). Sr and P negative anomalies are not attributed to mantle compositions but instead to possible cryptic apatite inclusion-bearing plagioclase fractionation (Cox et al. 1979) considering the degree of evolution of parental compositions. The spiked patterns for mobile incompatible elements may be due to small degrees of alteration.

A garnet harzburgite residual source could generate the $(\mathrm{La} / \mathrm{Yb})_{\mathrm{n}}$ ratio $(2,2)$ of the $\mathrm{H}$-Ti sample $1 \mathrm{UN} 32 / 254,10 \mathrm{~m}$ but this would require an extremelly high $\mathrm{K}_{\mathrm{d}}$ value $(-35$; Irving \& Frey 1978) and a $(\mathrm{La} / \mathrm{Yb})_{n}$ ratio lower than unity which is not consistent with the enriched characteristic of mantle sources as depicted by their patterns in multielemental diagrams. Partial melting of a harzurgitic source with $\mathrm{La} / \mathrm{Yb}$ ratio 1.6 times greater than chondritic values, lesser amounts of residual garnet $\left(1\right.$ vol.\%) and a lower $\mathrm{K}_{\mathrm{d}}$ value $(-1,67$; Irving \& Frey 1978) could give rise to both $1 \mathrm{UN} 06$ and 1UN32 H-Ti parental tholeiites within the range $(25 \%$ $45 \%$ ) required to generate tholeiitic basalts (eg., Mysen \& Kushiro 1977). It should be noted that those parental magmas could also be generated by a harzburgitic source with $\mathrm{La} / \mathrm{Yb}$ ratio 1.8 times greater than chondritic values and 3 vol.\% of residual spinel (Fig. 17). Considering the greater enrichment factor associated with the spinel peridotite source as well as no evidence for different degrees of $\mathrm{La} / \mathrm{Yb}$ fractionation in the multielemental diagram due to garnet control, these $\mathrm{H}-\mathrm{Ti}$ tholeiitic suites are likely to be related to an enriched spinel-bearing harzburgitic mantle source.

Boreholes 1UN19 and 1UN21 comprise L-Ti suites and are about $400 \mathrm{~km}$ apart from each other so that derivation

Table 4. Representative samples of parental magmas, their respective wells, $\mathrm{MgO}$ content (wt.\%) and $(\mathrm{La} / \mathrm{Yb})_{\mathrm{n}}$ and $(\mathrm{La} / \mathrm{Nb})_{n}$ ratios. High-TiO $2(\mathrm{H}-\mathrm{Ti})$ and low-TiO ${ }_{2}(\mathrm{~L}-\mathrm{Ti})$ suites are indicated.

\begin{tabular}{l|c|c|c|c}
\hline Sample & $\mathbf{M g O}$ & $(\mathrm{La} / \mathrm{Yb})_{\mathbf{n}}$ & $(\mathbf{L a} / \mathbf{N b})_{\mathbf{n}}$ & Suite \\
\hline 1UN06/176.20m & 6.49 & 2.1 & 1.3 & $\mathrm{H}-\mathrm{Ti}$ \\
\hline 1UN19/559.00m & 5.92 & 3.0 & 1.7 & $\mathrm{~L}-\mathrm{Ti}$ \\
\hline 1UN21/282.10m & 6.63 & 3.0 & 1.6 & $\mathrm{~L}-\mathrm{Ti}$ \\
\hline 1UN26/108.91m & 5.54 & 2.9 & 1.3 & $\mathrm{H}-\mathrm{Ti}$ \\
\hline 1UN26/76.30m & 5.49 & 2.9 & 1.6 & $\mathrm{~L}-\mathrm{Ti}$ \\
\hline 1UN32/254.10m & 6.68 & 2.2 & 1.4 & $\mathrm{H}-\mathrm{Ti}$ \\
\hline
\end{tabular}

from a single mantle source would indicate regional-scale geochemical heterogeneties in the SCLM. The patterns of these samples in a chondrite-normalized multielemental diagram (Fig. 18) show a $\mathrm{Nb}$ negative anomaly similarly to samples from boreholes $1 \mathrm{UN} 06$ and $1 \mathrm{UN} 32$. Other negative anomalies may have resulted from the same process depicted for borehole 1UN06 and 1UN32. As with the latter, there is no evidence for retention of garnet in the residual source in the patterns of the L-Ti suites in the chondrite-normalized multielemental diagram (Fig. 18).

It should be noted that the two L-Ti parental compositions have the same $\mathrm{La} / \mathrm{Yb}_{\mathrm{n}}$ ratio (3.0) but different $\mathrm{MgO}$ contents meaning that they had to be generated by different amounts of partial melting from different mantle sources. In accordance to derivation from the zone

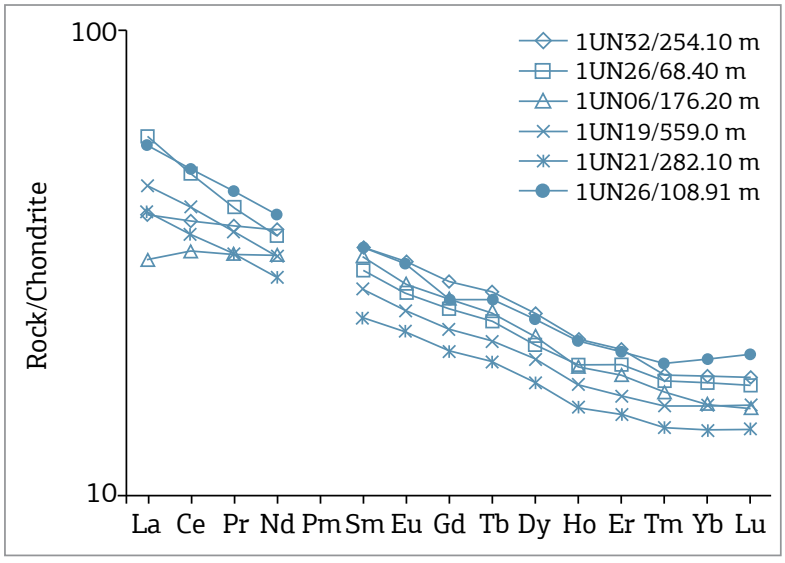

Figure 15. Chondrite-normalized REE diagram for samples representing parental compositions in the study area. Normalization factors from Evensen et al. (1978).

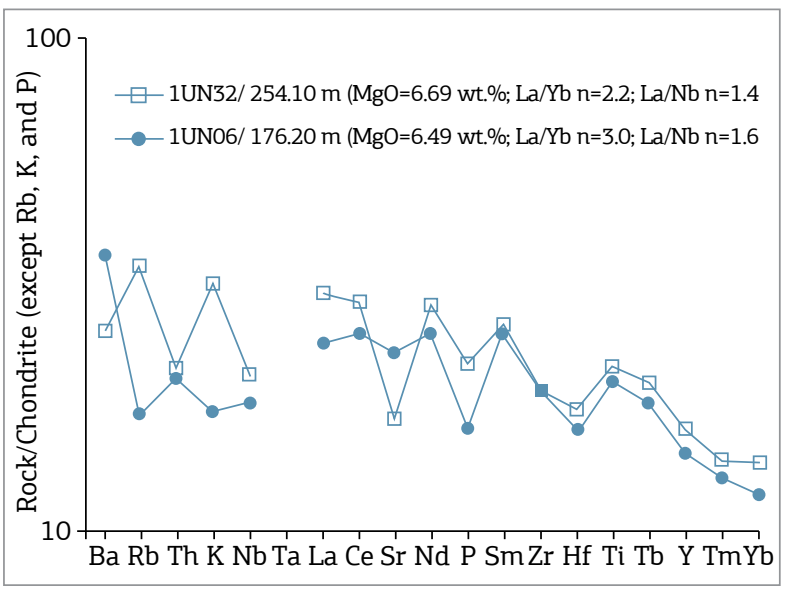

Figure 16. Chondrite-normalized multielemental diagram for samples representing $\mathrm{H}-\mathrm{Ti}$ parental compositions in boreholes 1UN06 and 1UN32. Normalization factors from Thompson (1982). 
of stability for spinel, the modal batch partial melting modelling showed that a harzburgitic mantle source with 3 vol.\% of residual spinel could generate the L-Ti suites either by $25 \%$ partial melting or by $45 \%$ partial melting from sources with $\mathrm{La} / \mathrm{Yb}$ ratios 2.4 and 2.7 times greater than the chondritic values, respectively. Keeping the parameters of the modelling, the results can also apply to the parental compositions of the $\mathrm{L}-\mathrm{Ti}$ and $\mathrm{H}-\mathrm{Ti}$ tholeiites from borehole $1 \mathrm{UN} 26$ with similar $\mathrm{MgO}$ contents and the same $\mathrm{La} / \mathrm{Yb}_{\mathrm{n}}$ ratios (Fig. 19).

In summary, the results of the partial melting models indicate that the Parnaíba L-Ti and H-Ti tholeiitic suites in the study area cannot be related to a single mantle source implying lateral geochemical heterogeneities in the SCLM within the spinel stability zone.

\section{PETROGENETIC MODEL}

A petrogenetic model that integrates the results shown in the previous sections is presented in Figure 20.

The Parnaíba tholeiites in the study area were derived from an enriched harzburgitic source in the zone of spinel likely to be related with the SCLM. The L-Ti and $\mathrm{H}-\mathrm{Ti}$ tholeiitic suites represented by samples in borehole 1UN26 located far north $\left(-3.5^{\circ} \mathrm{S}\right)$ can be generated by greater $(45 \%)$ and minor $(25 \%)$ amounts of partial melting from respectively more $\left(\mathrm{La} / \mathrm{Yb}_{\mathrm{n}}=2.8\right)$ and less $(\mathrm{La} /$ $\left.\mathrm{Yb}_{\mathrm{n}}=2.4\right)$ enriched portions of the SCLM. The same applies to the L-Ti tholeiitic suites in boreholes 1UN19

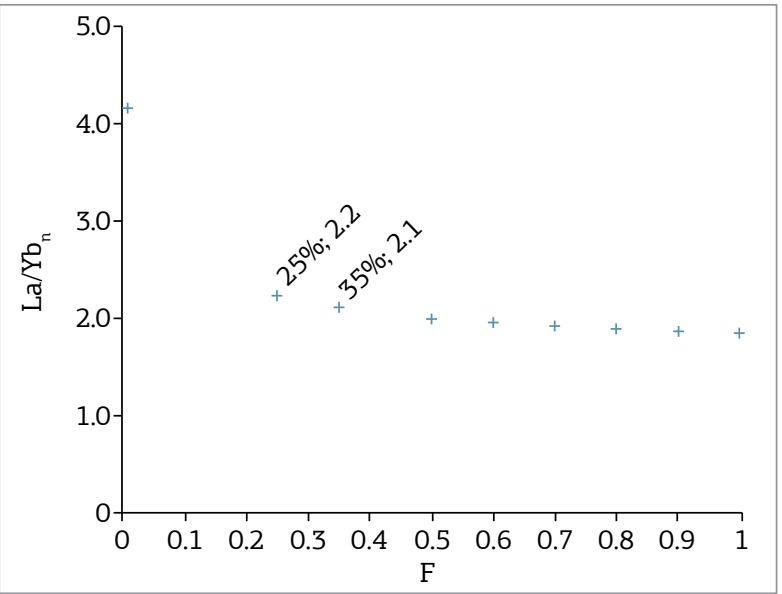

Figure 17. Fversus $\mathrm{La} / \mathrm{Yb}_{\mathrm{n}}$ diagram with the modal batch partial melting curve. Modal composition in the mantle residue (olivine:orthopyroxene:clinopyroxene:spinel = 68:27:2:3) is from McKenzie \& O'Nions (1991). The amount (\%) of partial melting and their respective $\mathrm{La} / \mathrm{Yb}_{\mathrm{n}}$ ratios are indicated. Crystal-liquid partition coefficients from Arth (1976) e Schock (1979). and 1UN21 (the latter located far south in the study area; $-7.5^{\circ} \mathrm{S}$ ). On the other hand, the H-Ti tholeiitic suites in boreholes $1 \mathrm{UN} 06$ and $1 \mathrm{UN} 32$ are related with a less enriched mantle source $\left(\mathrm{La} / \mathrm{Yb}_{\mathrm{n}}=1.8\right)$.

As such, the model proposes that the SCLM underneath the Parnaíba basin is geochemically heterogeneous on a scale of on a scale of hundreds of square kilometers. It is difficult to ascertain whether such heterogeneity is solely lateral since vertical heterogeneities seem to be necessary to explain the occurrence of L-Ti and H-Ti suites in the same borehole (1UN26).

The model also proposes that the primary tholeiitic magmas would segregate from their mantle sources and evolve mostly by fractional crystallization and AFC in relatively small magma chambers (possibly $\sim 10 \mathrm{~km}$ in

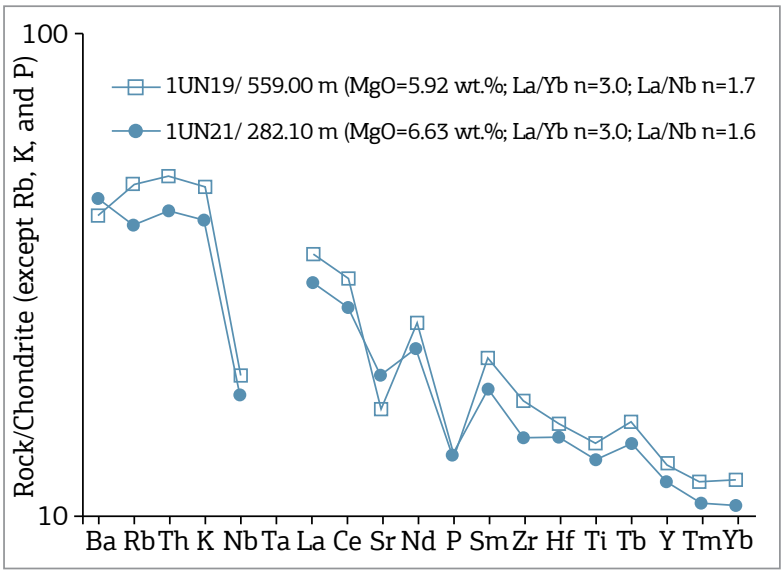

Figure 18. Chondrite-normalized multielemental diagram for samples representing $\mathrm{L}-\mathrm{Ti}$ parental compositions in boreholes 1UN19 and 1UN21. Normalization factors from Thompson (1982).

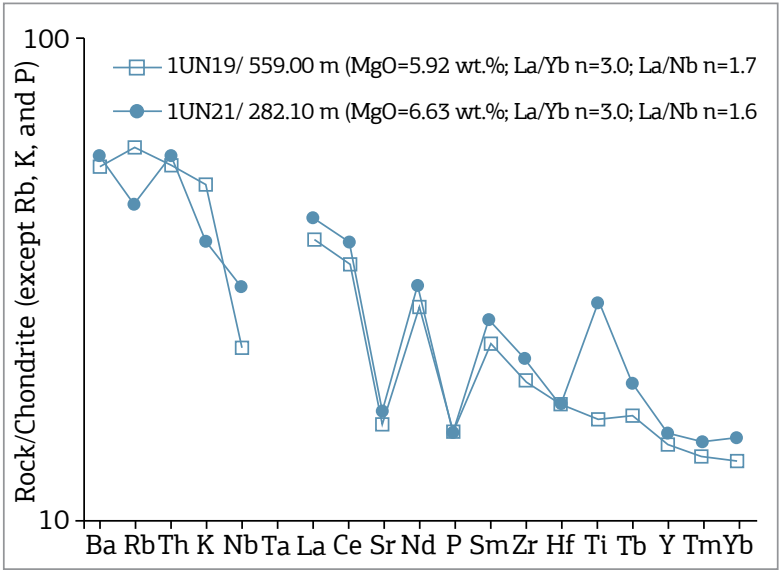

Figure 19. Chondrite-normalized multielemental diagram for samples representing L-Ti and $\mathrm{H}-\mathrm{Ti}$ parental compositions in borehole 1UN26. Normalization factors from Thompson (1982). 
diameter). Although basaltic magma chambers can be mapped along a few hundreds of kilometers worldwide, such as many layered intrusions (eg. Smith \& Kapp 1963, Namur et al. 2013), the existence of small basaltic magma chambers have been proved by geophysical and geochemical studies in slow-spreading ridge segments in the ocean floor (eg. Sleep 1975). Small magma chambers seem to be more liable to undergo extensive differentiation compared to large ones and, as such, will give rise to a wider compositional range of basalts (Nisbet $\&$ Fowler 1978). A densely fractured upper crust could provide a number of conduits fed from these magma chambers which in turn would give rise to various intrusions and eventually flows. Such conduits could well extend up to

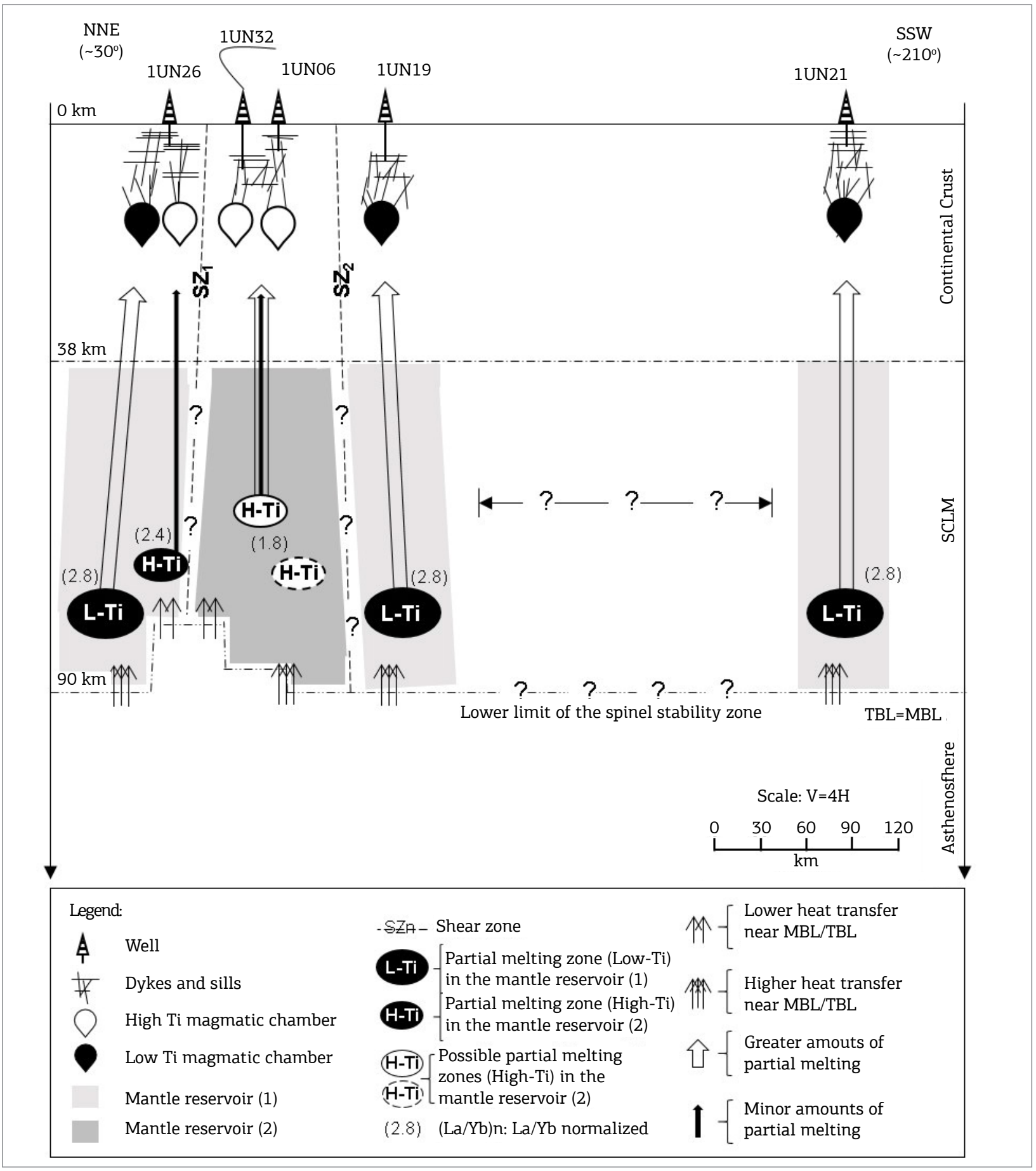

Figure 20. Petrogenetic model for the Parnaíba tholeiites in the study area. 
the sedimentary basin and give rise to the diabase sills studied in this work.

\section{TECTONIC CONTROLS ON MAGMA GENERATION}

The lack of geochronological data prevent refined correlations of the L-Ti and H-Ti tholeiites in the present study with tholeiitic basalts and diabases previously studied in the Parnaíba basin. The Mosquito and Sardinha basalts in the Parnaíba basin overlap when ploted on typical bivariate discriminant plots proposed for $\mathrm{L}-\mathrm{Ti}$ and $\mathrm{H}$-Ti suites elsewhere (eg. Peate 1997) as do the tholeiites of the present study (Fig. 21). As a gross approximation, the tholeiites sampled from the boreholes may be related to the Sardinha basalts since they are located eastwards the basin where most of the outcrops of the latter are found (Fig. 1). So, discussions will focus as much as possible on tectonic processes regardless the geodynamics possibly related with the studied tholeiites.

The boreholes align parallell to the NNE-trending Transbrasiliano lineament, which in turn follows approximately the lateral geochemical heterogeneities proposed in the petrogenetic model. Obviously, the extent of this lateral geochemical variation in the SCLM is difficult to calculate due to the restricted sampling from the boreholes. Nevertheless, preliminarly it could be asserted that lateral extensions oblique to N-S direction seem to be more plausible giving rise to NE-SW, NW-WE or even E-W trending

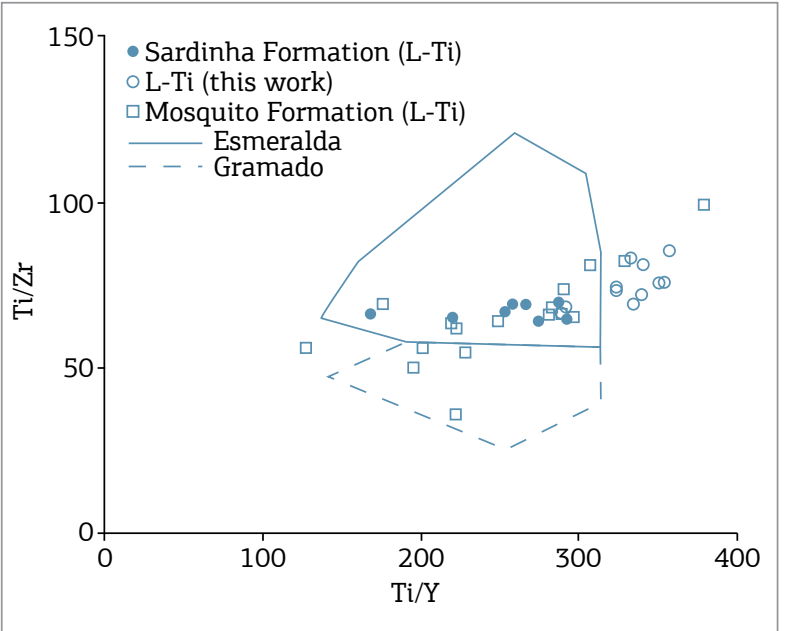

Figure 21. Discriminant diagram of low- $\mathrm{TiO}_{2}$ suites of Paraná-Etendeka Province (Peate 1997) with samples of low- $\mathrm{TiO}_{2}$ basalts of the Parnaíba Basin studied by other authors (Bellieni et al. 1990, Ernesto et al. 2004) and studied in this thesis. The discriminant field for the low- $\mathrm{TiO}_{2}$ basalts of Paraná-Etendeka are shown. borderlines. This rule out the control of the Transbrasiliano Lineament on tectonic processes that might have almalgamated distinctive lithosphere during past tectonic events. The origin of the geochemical provinciality depicted by the existence of L-Ti and H-Ti tholeiitic suites in the Parnaíba basin may not be related to different amounts of lithospheric thinning but instead to differential heat conduction from the underlain asthenospheric mantle. The nature of such thermal anomaly is beyond the scope of this work but $\approx$ the different amounts of heat conduction needed to explain the different amounts of partial melting of the SCLM may be related with an irregular, negative topography of the thermal (and mechanical) boundary layer (Fig. 20) inherited from previous orogenic processes.

\section{CONCLUSIONS}

The geochemical data obtained for tholeiitic basalts and diabases from borehole samples located easterwards the Parnaíba basin pointed to the existence of six tholeiitic suites being three $\mathrm{L}-\mathrm{Ti}$ and three $\mathrm{H}-\mathrm{Ti}$ ones in the study area. Results from geochemical modelling showed that fractional crystallization of augite and olivine and AFC can explain some relevant trace element and trace element ratios variations within suites. Local in-conduit, fluid-driven contamination was also discriminated in two boreholes. Mantle sources for the six tholeiitic suites are likely to be within the spinel stability zone in a variably enriched harzburgitic SCLM which seems to be in agreement with the existence of a relatively narrow continental crust underneath the sedimentary basin. Different degrees of partial melting from this heterogeneous source can account for the trace element compositions of the parental liquids. Lateral and/ or vertical, local-scale mantle heterogeneities seem not to have been controled by the Transbrasiliano Lineament but to reactivation of distinctive lithospheres amalgamated during previous orogenetic processes.

\section{ACKNOWLEDGMENTS}

Authors would like to thank GEOPARK for the financial support (Projeto Basalto) and the Departamento Nacional da Produção Mineral (DNPM) for giving access to the boreholes of Projeto Carvão, as well the LAGSED/ UFRJ for providing its lab facilities. Adriano Guilherme da Silva holds a scholarship from the Agência Nacional do Petróleo (PRH-ANP/MCT nº 18). Sérgio de Castro Valente holds a research grant provided by $\mathrm{CNPq}$ (proc. n. 306566/2012-5 - PQ-2). 


\section{REFERENCES}

Abelha M. 2013. Bacia do Parnaiba. Rio de Janeiro: ANP. 122 slides, color. Material elaborado para a 12. ${ }^{\text {a }}$ rodada de licitações de petróleo e gás. ANP, Superintendência de Definição de Blocos. Disponível em: <http://www.brasil-rounds.gov.br/arquivos/Seminarios_R12/ apresentacao/r12_04_parnaiba.pdf>. Acesso em: 25 maio 2014.

Aguiar G.A. 1969. Bacia do Maranhão: Geologia e Possibilidades de Petróleo. Recife, DNPM/CPRM. 75p. Relatório n.o 371.

Arth J.G. 1976. Behaviour of trace elements during magmatic processes - a summary of theoretical models and their applications. Journal of Research of the United States Geological Survey, 4:41-47.

Assumpção M., Feng M., Tassara A., Julià J. 2013. Crustal thickness map of Brazil: Data compilation and main features. Journal of South American Earth Sciences, 43:74-85.

Baksi A.K. \& Archibald D.A. 1997. Mesozoic igneous activity in the Maranhão province, northern Brazil: ${ }^{40} \mathrm{Ar} /{ }^{39} \mathrm{Ar}$ evidence for separate episodes of basaltic magmatism. Earth and Planetary Science Letters, 151(3-4):139-153.

Bellieni G., Piccirillo E.M., Cavazzini G., Petrini P., Comin-Chiaramonti P., Nardy A.J.R., Civetta A.J., Melfi A.J., Zantedeschi P. 1990. Lowand high $\mathrm{TiO}_{2}$, Mesozoic tholeitic magmatism of the Maranhão basin (NE-brazil) - K-Ar age, geochemistry, petrology, isotope characteristics and relationships with Mesozoic low- and high $\mathrm{TiO}_{2}$ flood basalts of the Paraná Basin (SE-Brazil). Neues Jahrbuch Mineralogischer Abhandlungen, 162:1-33.

Bertrand H. 1991. The Mesozoic Tholeitic Province of Northwest Africa: a volcanotectonic record of the early opening of Central Atlantic. In: Kampunzu A.B. \& Lubala R.T. (Eds.), Magmatism in Extensional Structural Settings. The Phanerozoic African Plate. Berlin, Springer-Verlag, p. 147-188.

Bond G.C., Nickeson P.A., Kominz M.A. 1984. Breakup of a supercontinent between $625 \mathrm{Ma}$ and $555 \mathrm{Ma}$ : new evidence and implications for continental histories. Earth and Planetary Science Letters, 70(2):325-345.

Castro D.L., Fuck R.A., Phillips J.D., Vidotti R.M., Bezerra F.H.R., Dantas E.L. 2014. Crustal structure beneath the Paleozoic Parnaíba Basin revealed by airborne gravity and magnetic data, Brazil. Tectonophysics, 614:128-145.

Cox K.G., Bell J.D., Pankhurst R.J. 1979. The interpretation of igneous rocks. London, George Allen \& Unwin, 450p.

DePaolo D.J. 1981. Trace element and isotopic effects of combined wall-rock assimilation and fractional crystallization. Earth and Planetary Science Letters, 53:189-202.

Erlank, A.J., Marsh, J.S., Duncan, A.R., Miller, R., Hawkesworth, C.J., Betton, P.J. \& Rex, D.C. 1984. Geochemistry and petrogenesis of the Etendeka volcanic rocks from SW Namibia. Special Publication of the Geological Society of South Africa, 13, 195-246.

Ernesto M., Marques L.S., Bellieni G., Piccirillo E.M., DeMin A. Pacca I.G., Martins G., Macedo J.W.P. 2004. As Rochas Toleíticas Mesozoicas do Nordeste do Brasil: Distribuição Espacial e Temporal dos Sucessivos Episódios Magmáticos. In: Congresso Brasileiro de Geologia, 42., 2004, Araxá. Anais do XLII Congresso Brasileiro de Geologia. CD. p.783.

Evensen N.M., Hamilton P.J., O'Nions R.K. 1978. Rare-earth abundances in chondritic meteorites. Geochimica et Cosmochimica Acta, 42(8):1199-1212

Faure G. 1986. Principles of isotope geology. New York, John Wiley \& Sons, 590p.
Fodor R.V., Sial A.N., Mukasa S.B., McKee E.H. 1990. Petrology, isotope characteristics, and K-Ar ages of the Maranhão, northern Brazil, Mesozoic basalt province. Contributions to Mineralogy and Petrology, 104(5):555-567.

Goes A.M.O., Souza J.M.P., Teixeira L.B. 1990. Estágio exploratório e perspectivas petrolíferas da Bacia do Parnaíba. Boletim de Geociências da Petrobras, 4:55-64

Hansen J. 2015. A numerical approach to sill emplacement in isotropic media: do saucer-shaped sills represent "natural" intrusive tendencies in the shallow crust? Tectonophysics, 664:125-138

Hoyle J., Elderfield H., Gledhill A., Greaves M. 1984. The behavior of the rare earth elements during mixing of river and seawaters. Geochimica et Cosmochimica Acta, 48:143-149.

Humphries S.E. 1984. The mobility of the rare earth elements in the crust. In: Henderson P. (Ed.). Rare earth element geochemistry. New York: Elsevier. p.317-342

Irvine T.N. \& Baragar W.R.A. 1971. A Guide to the Chemical Classification of the Common Volcanic Rocks. Canadian Journal of Earth Sciences, 8(5):523-548.

Irving A.J. \& Frey F.A. 1978. Distribution of trace elements between garnet megacrysts and host volcanic liquids of kimberlitic to rhyolitic composition. Geochimica et Cosmochimica Acta, 42:771-787.

Jenner G.A. 1996. Trace Element Geochemistry of Igneous Rocks: Geochemical Nomenclature and Analytical Geochemistry. In: Wyman D.A. (Ed.), Trace Element Geochemistry of Volcanic Rocks: Applications for Massive Sulphide Exploration. Canada, Geological Association of Canada, v.12, p.51-77.

Jenner G.A., Longerich H.P., Jackson S.E., Fryer B.J. 1990. ICP-MS a powerful tool for high precision trace element analyses in earth sciences: evidence from analyses of selected U.S.G.S. reference samples. Chemical Geology, 83:133-148.

Johnson K.T.M. 1998. Experimental determination of partition coefficients for rare earth and high-field-strength elements between clinopyroxene, garnet, and basaltic melt at high pressures. Contributions to Mineralogy and Petrology, 133(1-2):60-68.

Le Bas M.J, Le Maitre R.W, Streckeisen A., Zanettin B. 1986 A chemical classification of volcanic rocks based on the total alkali-silica diagram. Journal of Petrology, 27:745-750.

Le Maitre R.W. (Ed.). 2002. Igneous Rocks. A Classification and Glossary of Terms: Recommendations of the International Union of Geological Sciences Subcommission on the Systematics of Igneous Rocks. 2nd. ed. Edinburg, Cambridge University Press. 236p.

Lima Neto H.C. 2013. Sismicidade e correlação com feições geológicas: o caso do lineamento Pernambuco e seu entorno. Doctoring thesis, Universidade Federal do Rio Grande do Norte, Rio Grande do Norte, 171p.

Maaløe S. \& Aoki K. 1977. The major element composition of the upper mantle estimated from the composition of lherzolites. Contributions to Mineralogy and Petrology, 63:161-173.

Mackenzie W.S., Donaldson C.H., Guilford C. 1982. Atlas of Igneous Rocks and their Textures. London, Longford. 148p.

Marzoli A., Renne P.R., Piccirillo E.M.. Ernesto M., Bellieni G. DeMin A. 1999. Extensive 200-Million-Year-Old Continental Flood Basalts of the Central Atlantic Magmatic Province. Science, 284(5414):616-618. 
McKenzie D. \& O’Nions R.K. 1991. Partial melt distributions from inversion of rare earth element concentrations. Journal of Petrology, 32:1021-1091.

Merle R., Marzoli A., Bertrand H., Reisberg L., Verati C., Zimmermann C., Chiaradia M., Bellieni G., Ernesto M. 2011. ${ }^{40} \mathrm{Ar} /{ }^{39} \mathrm{Ar}$ ages and $\mathrm{Sr}-\mathrm{Nd}-\mathrm{Pb}-\mathrm{Os}$ geochemistry of CAMP tholeiites from Western Maranhão basin (NE Brazil). Lithos, 122(3-4):137-151.

Middlemost E. 1989. Iron oxidation ratios, norms and the classification of volcanic rocks. Chemical Geology, 77:19-26.

Mysen B.O. \& Kushiro I. 1977. Compositional variations of coexisting phases with degree of melting of peridotite in the upper mantle. American Mineralogists, 62:843-865.

Namur O., Humphreys M.C.S., Holness M.B. 2013. Lateral reactive infiltration in a vertical gabbroic crystal mush, Skaergaard intrusion, East Greenland. Journal of Petrology, 54:985-1016.

Nisbet E.G. \& Fowler M.R. 1978. Mid-Atlantic Ridge at $37^{\circ}$ and $45^{\circ}$ N: some geophysical and petrological constraints. Geophys. Journal R. Astron. Society, 54:631-660.

Oliveira D.C. \& Mohriak W.U. 2003. Jaibaras trough: an important element in the early tectonic evolution of the Parnaiba interior sag basin, Northern Brazil. Marine and Petroleum Geology, 20(3-4):351-383.

Pearce J.A. 1983. Role of the sub-continental lithosphere in magma genesis at active continental margins. In: Hawkesworth C.J. \& Norry M.J. (Eds.). Continental basalts and mantle xenoliths. Nantwich, Cheshire: Shiva Publications, p.230-249.

Peate D.W. 1997. The Parana-Etendeka province. In: Mahoney J.J. \& Coffin M.F. (Eds.). Large igneous provinces: continental, oceanic and planetary flood volcanism. American Geophysical Union, 100, p.217-245. Geophysical Monograph Series.

Piccirillo E.M. \& Melfi A.J. (Eds.). 1988. The Mesozoic Flood Volcanism of the Paraná Basin: Petrogenetic and Geophysical Aspects. São Paulo, Instituto Geofísico, Astronômico e Ciências Atmosféricas, Universidade de São Paulo, 600p.

Porto A.L. \& Pereira E. 2014. Seismic Interpretation of Igneous Intrusions and Their Implications for an Unconventional Petroleum System in Southeastern Parnaiba Basin, Northeastern Brazil.
In: American Geophysical Union, Fall Meeting 2014. Abstract \#V51B-4753.

Rodrigues R. 1995. A Geoquímica Orgânica na Bacia do Parnaiba. Porto Alegre (RS). Tese (doutorado). Universidade Federal do Rio Grande do Sul, Rio Grande do Sul, 225p.

Roeder P.L. \& Emslie R.F. 1970. Olivine-liquid equilibria. Contributions to Mineralogy and Petrology, 29:275-289.

Rollinson H.R. 1993. Using Geochemical Data: Evaluation, Presentation, Interpretation. Edinburgh: Longman, $352 \mathrm{p}$.

Schock H.H. 1979. Distribution of rare-earth and other trace elements in magnetites. Chemical Geology, 26:119-133.

Sleep N.H. 1975. Formation of oceanic crust: some thermal constraints. Journal of Geophysical Research, 80:4037-4042.

Smith C.H. \& Kapp H.E. 1963. The Muskox Intrusion, a recently discovered layered intrusion in the Coppermine River Area, Northwest Territories, Canada. Mineralogical Society of America, 1:30-35.

Taylor S.R. \& McLennan S.M. 1981. The composition and evolution of the continental crust: rare earth element evidence from sedimentary rocks. Philosophical Transactions of the Royal Society of London, A301:381-399.

Thompson R.N. 1982. Magmatism of the British Tertiary Volcanic Province. Scottish Journal of Geology, 18(1):49-107.

Tsay A., Zajacz Z., Sanchez-Valle C. 2014. Efficient mobilization and fractionation of rare-earth elements by aqueous fluids upon slab dehydration. Earth and Planetary Science Letters, 398:101-112.

Vaz P.K., Rezende N.G.A.M., Wanderley Filho J.R., Travassos W.A.S. 2007. Bacia do Parnaíba. Boletim de Geociências da Petrobras, 15:253-263.

Wilson M. 1989. Igneous petrogenesis: a global tectonic approach. Canada, Harper Collins Academic, 466p.

Wood B.J. \& Fraser D.G. 1976. Elementary thermodynamics for geologists. Oxford, Oxford University Press. 303p.

Available at www.sbgeo.org.br 